\title{
Work Event Experiences: Implications of an Expanded Taxonomy for Understanding Daily Well-Being
}

\author{
Gudrun Reindl ${ }^{1}$, Jonas W. B. Lang ${ }^{1,2}$, and J. Malte Runge ${ }^{1}$ \\ ${ }^{1}$ Department of Human Resource Management and Organizational Psychology, Ghent \\ University, Belgium \\ ${ }^{2}$ Business School, University of Exeter, UK
}

\begin{abstract}
Author Note
Gudrun Reindl (id https://orcid.org/0000-0003-0955-6286

Jonas W. B. Lang (D) https://orcid.org/0000-0003-1115-3443

J. Malte Runge (DiD https://orcid.org/0000-0003-0594-6578

Some of the data reported in Study 1 was presented at the annual meeting of the DutchFlemish Work and Organizational Psychology Association (Werkgemeenschap van Onderzoekers in de Arbeids- en Organisatiepsychologie; WAOP) in 2018 and at the annual meeting of the Society for Industrial and Organizational Psychology (SIOP) in 2019. We thank Justine Amory, Larissa Bael, Jenna Bloem, Sarah Foets, An De Schampheleire, Sigi Palinckx, and Roxanne Verheyen for their help in collecting the data.

Correspondence concerning this article should be addressed to Gudrun Reindl, Department of Human Resource Management and Organizational Psychology, Ghent University, 9000 Ghent. Email: gudrun.reindl@ugent.be
\end{abstract}


(C) 2020, American Psychological Association. This paper is not the copy of record and may not exactly replicate the final, authoritative version of the article. Please do not copy or cite without authors' permission. The final article will be available, upon publication, via its DOI: 10.1037/ocp0000276 


\begin{abstract}
This article builds on earlier research on work events and uses a recently developed taxonomy of situation perceptions - the CAPTION taxonomy — to study daily work events. The authors specifically test the ideas that the specific affective event dimensions A (Adversity) and $\mathrm{O}$ (hum $\underline{\text { r) }}$, and cognitive and typicality dimensions-I (Importance), C (omplexity), and T (Typicality)—contribute to explaining daily well-being beyond P (Positive valence) and $\mathrm{N}$ (Negative valence). Study 1 included $N=242$ employees who filled in a diary over five workdays, and Study 2 included a total of 295 employees in an experience sampling design. Results from multilevel confirmatory factor analyses with events nested in persons and days nested in persons suggested that a 7-dimension model—in line with the CAPTION taxonomyimproved model fit. Multilevel structural equation modeling further revealed that the additional dimensions contributed to explaining well-being after work (Study 1) and well-being at work (Study 2) at both the between- and the within-person level. These effects were in particular driven by the A (Adversity) and $\mathrm{O}$ (hum $\underline{\mathrm{Or}}$ ) dimensions. The authors discuss to what degree a multidimensional perspective on situation perceptions can improve occupational health researchers' understanding of work events as drivers of well-being at work. Keywords: work events, situations, CAPTION, affective well-being, ESM
\end{abstract}




\section{Work Event Experiences: Implications of an Expanded Taxonomy for Understanding Daily Well-Being}

In the past 20 years, occupational health $(\mathrm{OH})$-psychologists have shown an increasing interest in studying events at work. Work events are typically described as cohesive situations in organizations that diverge from work routine (Morgeson et al., 2015). Examples are the presentation of a project, a supervisor-meeting, or a personal compliment handed out by a colleague. Past research suggests that work events are related to important employee outcomes like their mood and fatigue (Gross et al., 2011; Zohar et al., 2003), work engagement (Demerouti \& Cropanzano, 2016), and work-role behavior (Matta et al., 2014).

An influential idea in the literature is that work events elicit affective reactions in employees that then influence their thoughts and behaviors (Morgeson et al., 2015; Rentsch, 1990; Weiss \& Cropanzano, 1996). Affective reactions are typically described using a twodimensional taxonomy with a positive and a negative dimension (Watson et al., 1988). Based on the idea that events are closely tied to affective reactions, researchers have typically used this positive/negative taxonomy to describe work events and study their impact on well-being (Bledow et al., 2011; Fuller et al., 2003; Gross et al., 2011; Zohar et al., 2003; see Ohly \& Schmitt, 2015 for an exception). Although the positive/negative taxonomy has been useful in past research on work events, several research streams suggest that capturing and understanding events may benefit from more elaborate frameworks that go beyond broad affect (Edwards \& Templeton, 2005; Johns, 2006; Meyer et al., 2010; Mischel \& Shoda, 1995; Morgeson et al., 2015).

One important research stream providing hints for important aspects that go beyond broad affect has developed in the organizational sciences starting with Johns' (2006) article on 
context. Johns suggested that organizational researchers do not sufficiently take the situational aspects of organizational behavior into account, and highlighted that context has many facets of which situational strength may be especially important for understanding behavior in organizations. Building on this work, Meyer et al. (2010) suggested that situational strength is particularly characterized by clarity, consistency, constraints, and consequences. More recently, several of these ideas have been extended to events, and the resulting theoretical frameworkevent system theory (short: EST, Morgeson et al., 2015)—suggests that the event/behavior link is characterized by three core event dimensions - novelty, criticality, and disruption - that go beyond affective perceptions and determine situational strength.

A second research stream that provides clues for important aspects of events beyond broad affect dimensions has recently developed in personality psychology. Researchers in this area have focused on developing multidimensional taxonomies of situation perceptions with five to eight dimensions (Parrigon et al., 2017; Rauthmann et al., 2014; Ziegler et al., 2019). In addition to two general dimensions capturing the positivity and negativity of situations, these taxonomies include dimensions for specific affectivity, cognitive load, and typicality of the situation. Existing work in this area is not specifically work-related or focused on explaining outcomes or sequences of events in organizations. Instead, the primary emphasis is on developing taxonomies of subjective situation perceptions that are as comprehensive as possible and can function as useful measurement instruments.

In this article, we extend existing work on the link between event perceptions and daily occupational well-being. Our article contributes to the literature on work events in two ways. First, we follow calls in the existing literature (Johns, 2006; Meyer et al., 2010) to more systematically study the dimensionality of work event perceptions. We thus use multilevel factor 
analysis to gain insights into the usefulness of an extended multidimensional taxonomy that also includes cognitive and strength dimensions. In so doing, we build on recent perspectives on situational strength (Johns, 2006; Meyer et al., 2010), events in organizational systems (Morgeson et al., 2015), and the multidimensionality of situation perceptions (Parrigon et al., 2017; Rauthmann et al., 2014; Ziegler et al., 2019). Our starting point is the Complexity,

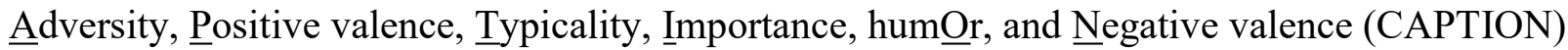
taxonomy and we apply this taxonomy to work events. Second, we build directly on event system theory (Morgeson et al., 2015) and study the degree to which additional event perception dimensions (beyond positivity/negativity) extend occupational health researchers' understanding of daily and event-related fluctuations in well-being in diary and experience sampling designs. Our article includes two studies. The first study uses a diary design and links work events to daily well-being (after-work emotional exhaustion, positive, and negative affect), the second study is based on an experience sampling method (ESM) design and focuses on work events and event-related discrete emotions.

\section{Events at Work}

Work events have been described as occurrences within an organization that employees consider relevant or meaningful for either themselves or the organization (Rentsch, 1990). Researchers also suggested that work events have three main characteristics (Morgeson et al., 2015). First, work events happen in the environment and are thus outside of the employee's control. Second, work events lead to psychological reactions in the employee, e.g., affective reactions to the event (psychological reactions). Third, work events occur at a particular place and time and have a clear beginning and end. Therefore, work events are discrete and 
discontinuous (discreteness), and thus differ from the majority of other situations that are frequently characterized by stability and the presence of routines (Morgeson et al., 2015).

\section{Research on Work Event Experiences and Well-Being}

$\mathrm{OH}-$ and work psychologists have been particularly interested in how subjective experiences of work events influence employees' well-being (e.g., Bono et al., 2013; Hoobler et al., 2010; Kuba \& Scheibe, 2017; Weiss \& Cropanzano, 1996; Zohar et al., 2003). Most research in this area has focused on the affectivity of work events as a key defining feature (e.g., Basch \& Fisher, 1998; Grandey et al., 2002; Gross et al., 2011). This affectivity perspective (Weiss \& Cropanzano, 1996) suggests that work events frequently evoke a positive or negative emotional reaction in employees, and these affective interpretations of events then shape employees' daily well-being.

Table 1 provides an illustrative overview of findings that link work-event perceptions to daily well-being in work psychology journals since the release of the affective event framework in 1996. As shown in Table 1, most measurement approaches for subjective experiences of work events have built on measures for affect and have adjusted them to specifically capture workevent-related affect. The most commonly used measurement approach for affect is the twodimensional positive/negative affect taxonomy (Watson et al., 1988), and most existing approaches for measuring subjective experiences of work-events, therefore, adopt a distinction between positive and negative work events or reactions to work events. Our literature review (also see Table 1) revealed three core approaches used in extant research.

The first approach provides employees with a fixed list of positive and negative events and asks them to indicate events that occurred during the day. Researchers then sum up the total 
number of positive and negative events to positive and negative event scores (Bono et al., 2013; Ilies, Keeney, et al., 2011; Zohar et al., 2003; Hoobler et al., 2010; Volmer et al., 2012).

The second approach is somewhat similar to the first one but does not use a fixed list of events. This approach instead first asks employees to freely describe the work events and their experiences related to the event with a few sentences. In a second step, the respondents are asked to specify whether they experienced the event as positive or negative. Researchers typically aggregate the combined counts of experienced positive and negative events to a total positive and total negative event score (Fuller et al., 2003; Gross et al., 2011; Kuba \& Scheibe, 2017).

A third and more recent approach first asks employees to describe both positive and negative work events and related experiences using open questions. In the next step, the researchers sort these event descriptions into clusters (Ohly \& Schmitt, 2015). For instance, a recent study using this approach (Ohly \& Schmitt, 2015) assigned an event described by the employee as “The PC was broken-down” (p. 27) to a cluster called "Technical difficulties, problems with work tools and equipment" (p. 27). Although the three described approaches differ in how they capture work events, these approaches share the common feature in that they rate work events as either positive or negative.

Table 1 also provides some useful insights into typical findings in this research area. As shown in Table 1, research has found that negative work-event perceptions negatively relate to well-being by increasing fatigue and exhaustion (Gross et al., 2011; Kuba \& Scheibe, 2017), perceived strain (Bono et al., 2013), as well as blood pressure (Bono et al., 2013). Table 1 also indicates that earlier research found that positive perceptions of work events positively relate to positive affect after work (Koopmann et al., 2016), job satisfaction (Ilies, Keeney, et al., 2011), 
work engagement (Bledow et al., 2011), physical and mental health (Hoobler et al., 2010b;

Volmer et al., 2012), and general life satisfaction (Ilies, Keeney, et al., 2013).

\section{Context, Situations, and Event Systems in Organizational Research}

Work that is relevant for understanding events has also been discussed outside well-being research. Johns (2006) wrote an influential article on context which suggests that organizational researchers should take situational aspects in organizations more broadly into account. Johns argued that situational strength may be important to understanding context and that organizational researchers should study different aspects of situational strength. Following this call, Meyer et al., (2010) conceptually studied situational strength and theoretically suggested that situational strength can be characterized by clarity, consistency, constraints, and consequences. More recently, Morgeson et al. (2015) extended several of these ideas to events and integrated two streams of existing theory in organizational sciences, namely open system theory (Katz \& Kahn, 1978) and process theories (Rescher, 1962). In the resulting theoretical framework - the event system theory - Morgeson et al. (2015) suggest that three core event dimensions affect the event/behavior link. These core dimensions—novelty, criticality, and disruption — go beyond affective reactions and determine situational strength. The primary emphasis in this theoretical framework is on explaining when events affect behavior and features of organizational entities and trigger subsequent events.

\section{Psychological Situations and Their Dimensionality}

Research on situation characteristics has long suggested that measuring characteristics of situations is challenging. From a theoretical perspective, Rauthmann et al. (2015) suggested three ways to describe situations. 
The first approach is to characterize situations by cues. Cues are physical elements or features of a situation (who did what, where, when, and why?) that can allow researchers to describe a given situation in a relatively objective way. For example: "An employee and their supervisor (who?) have a meeting (what?) in the supervisor's office (where?) at noon (when?) to discuss the stage of the current project (why?)."

The second approach groups situations into similar classes. For instance, the office situation mentioned in the previous paragraph as an example can be classified as a social situation or as an anxiety-evoking situation depending on the focus of the researcher. An advantage of describing situations by grouping similar situations into classes is that this approach is relatively simple and easy to understand. However, researchers argued that the use of this approach also limited early attempts to study situations to specific "types" of situations, and discouraged research from considering the full range of possible situations (see Horstmann et al., 2018 for an overview).

The third approach is the focus of the present article and is commonly known as situation measurement. This approach purposefully includes the person's subjective perception of a situation and focuses on capturing situation characteristics through the lens of these subjective experiences (Rauthmann et al., 2015). Individual experiences of situations, as captured by the situation measurement approach, have also been described as psychological situations (Parrigon et al., 2017; Rauthmann et al., 2014; Ziegler et al., 2019). An advantage of this approach is that two people may experience and interpret the objectively same situation in two different ways (e.g., helpful vs. frustrating). The two diverging experiences will likely result in different affective reactions, thoughts, and behavior. Therefore, it can be useful to study the psychological characteristics of situations. In the office example in the paragraph before the previous 
paragraph, for instance, the supervisor may report that they and the employee had a constructive meeting, in which they gave useful advice on how to proceed with the project. In contrast, the employee may report a frustrating meeting during which the supervisor criticized their work.

Studying psychological situations has long been difficult because of a lack of established taxonomies and measures. However, personality psychologists recently addressed this crucial problem and developed novel measures and taxonomies for psychological situations. To build those taxonomies, researchers have used two different strategies- top-down and bottom-up. In the top-down approach, researchers develop items and scales for a theoretically derived taxonomy (see Brown et al., 2015 for an example based on evolutionary and motivational theory). In contrast, bottom-up approaches try to sample a comprehensive set of items and then use empirical methods like factor analysis to develop a stable taxonomy. Most recently developed situation taxonomies that are widely used in the literature have been developed based on this bottom-up approach (Parrigon et al., 2017; Rauthmann et al., 2014; Ziegler et al., 2019).

One frequently used example is the eight-dimensional Duty, Intellect, $\underline{\text { Adversity, }}$ Mating, pO-sitivity, Negativity, Deception, and Sociality (short DIAMONDS; Rauthmann et al., 2014) taxonomy. This taxonomy has been extracted from a comprehensive list of situations that provide an opportunity for people to express their personality.

The Situation Five (Ziegler et al., 2019) is based on a lexical approach. The basic assumption of lexical approaches is that situational perceptions are embedded in human language. To develop their items using a lexical approach, Ziegler et al. (2019) therefore screened dictionaries for adjectives that describe situations.

In this study, we focus on a third bottom-up taxonomy — the seven-dimensional Complexity, Adversity, Positive valence, Typicality, Importance, hum $\underline{\text { Or}}$, and Negative valence 
(short CAPTION; Parrigon et al., 2017) taxonomy to assess situations. CAPTION is also based on a lexical approach. However, Parrigon et al. (2017), screened movie subtitles instead of dictionaries. Their rationale was that movies consist of an array of situations and contain adjectives describing the ongoing scene and thus provide a rich resource of situation descriptions.

\section{Expanding the Taxonomy of Work Event Experiences}

Our goal in this article was to integrate work on events in organizational research (e.g. Morgeson et al., 2015) with recent work on situation taxonomies (e.g., Parrigon et al., 2017). In so doing, we built on existing work on events and well-being, and on research on situational strength (e.g., Meyer et al., 2010) and events in organizational behavior. We decided to rely on the CAPTION taxonomy because this taxonomy is particularly suitable to study work events. The way Parrigon et al. (2017) and the broader literature on situation perception conceptualize situations is closely related to Morgeson et al.'s (2015) definition of work events. First, general situations are "a constellation of actions, objects, organisms, and place" (Edwards \& Templeton, 2005, p. 706). These actions, objects, organisms, and places form the environment of the perceiver - a central feature of event definitions (Morgeson et al., 2015). Second, situations influence objects and actors but also depend on individual perception (Edwards \& Templeton, 2005; Parrigon et al., 2017). This situation feature matches the psychological reactions of events (Morgeson et al., 2015). Finally, actions, objects, actors, and places coexist at a particular time period (Edwards \& Templeton, 2005; Pervin, 1978). Events are also defined as co-occurrence of place and time (Morgeson et al., 2015). However, an important difference between situations in the CAPTION taxonomy and typical definitions of work events is the fact that situations are not necessarily limited to a clear beginning and an end. Accordingly, situations, unlike work events, 
can be part of a continuous routine. Work events are discrete and discontinuous and commonly interrupt routines. Because of this difference, it seems important to test whether or not the CAPTION taxonomy can be applied to capture work events. Another difference in addition to the event nature of work events is the fact that CAPTION has to our knowledge not been developed with work in mind so it is also important to assess the degree to which the taxonomy can be used in this context.

A second advantage of the CAPTION taxonomy is that it includes dimensions that correspond with the traditional positive/negative event taxonomy next to dimensions that match the situational strength dimensions suggested in EST. Positive valence (P) includes sociality, intimacy, and general positivity of the situation and negative valence $(\mathrm{N})$ describes malicious or sinister situations. These two dimensions align with the traditional view on affective work events. Adverse situations (A) deplete resources, induce stress, or expend energy. Adversity in CAPTION corresponds with the disruption dimension in EST. Typicality (T) distinguishes common and well-known from new and ambiguous situations and, thus, matches with the novelty dimension in EST. Importance (I) determines whether the situation is relevant for specific goals and covers the EST dimension criticality.

Additionally, CAPTION encompasses the dimensions complexity and humor that also have already been studied in the context of situations and events at work (Horton \& Griffin, 2017; Robert \& Wilbanks, 2012). The complexity (C) dimension describes cognitively complex and scholarly situations that demand in-depth thinking or learning. The humor $(\mathrm{O})$ dimension comprises positive light-hearted (e.g., goofy) and darkly humorous (e.g., childish or mischievous) situations.

\section{Hypotheses}


As noted earlier, the goal of this article was to extend existing research on relationships between work event experiences and well-being by introducing an extended multidimensional view and measurement approach for work event experiences. Earlier research has established that it is useful to measure work events by capturing work-event-related positive and negative affect (Bono et al., 2013; Casper et al., 2019; Gross et al., 2011). The overarching research question of this article was to study whether applying the CAPTION taxonomy to work events is useful and provides additional insights. CAPTION expands the two dimensional positive/negative taxonomy with specific affective (humor and adversity), cognitive (complexity and importance), and typicality characteristics in addition to the already established positive/negative dimensions. Figure 1 provides an overview of our hypotheses and study variables.

\section{Dimensionality at the Within- and Between-Person Level}

To study whether the additional CAPTION dimensions capture work events and provide important additional insights, we first studied the dimensionality of work event perceptions at both the within- and between-person level using multilevel factor analysis (e.g., Colquitt, 2001; Dyer et al., 2005; Roesch et al., 2010). We compared the seven-dimensional CAPTION taxonomy to a simpler positive/negative taxonomy. Additionally, we also contrasted the CAPTION taxonomy with a four-dimensional taxonomy (positivity, negativity, cognition, and typicality). The four-dimensional taxonomy derived from a synopsis of multiple situation taxonomies in personality psychology (Rauthmann et al., 2019) and omits specific subdimensions of the CAPTION taxonomy.

Situation taxonomies have typically been used to investigate between-person differences in trait situational characteristics (Parrigon et al., 2017; Ziegler et al., 2019). Although between- 
person effects are interesting to study, situation characteristics may not only differ from one person to another but may also differ across multiple situations. Because mechanisms at the between-level do not necessarily generalize to the within-level (Chen et al., 2005; Curran \& Bauer, 2012), it is necessary to study whether the proposed CAPTION factor structure generalizes from the between- to the within-person level. To illustrate this point, it may be possible that a person more easily starts laughing and characterizes situations generally as funnier than another person $(\mathrm{O})$ while the second person is more vulnerable for sentimental warmth than the first (P). However, when both persons characterize a specific situation as funny (O), they might both also perceive the situation as warm and positive $(\mathrm{P})$.

Hypothesis 1: A 7-dimensional CAPTION taxonomy will provide a better fit to daily work events data than a two-dimensional (positivity, negativity) event taxonomy and than a general 4-dimensional (positivity, negativity, cognition, typicality) situation taxonomy a) at the between-person level and b) the within-person level.

\section{Added Value of CAPTION in Explaining Daily Well-Being}

In the next step, we studied the degree to which these dimensions are related to daily well-being outcomes. In the two studies we conducted, we focused on a total of seven different daily well-being criteria. In the first study, we measured emotional exhaustion and positive/negative affect in the evening as typical broad daily well-being measures (Watson et al., 1988). Emotional exhaustion is the core dimension of burnout and is typically defined as physical and emotional fatigue due to extensive work exposure (Maslach et al., 2001; Sonnentag, 2017). Additionally, we used general positive and negative affect in the evening as outcome variables. General positive and negative affect is not related to a particular event and thus conceptually differs from work-event-related positivity/negativity dimensions discussed earlier. 
These general positive and negative affect measures are not limited to the interpretation of the event and are thus not constrained in place and time (Maslach et al., 2001; Watson et al., 1988).

In the second study, we used a momentary assessment approach and gathered multiple measurements of well-being each day. Because of the more limited time-frame in this second study, we focused on four discrete emotions: joy, pride, anger, and guilt (Barclay et al., 2005; Gooty et al., 2014; Grandey et al., 2002; Hillebrandt \& Barclay, 2017; Rupp \& Spencer, 2006; Spencer \& Rupp, 2009; Weiss et al., 1999). Discrete emotions capture subcomponents of positive/negative affect and are thus more specific and more closely linked to facial expressions (Ekman, 1993; Feldman Barrett \& Russell, 1998). For assessing discrete emotions, we apply the emotion framework of Weiss et al., (1999). The framework is composed of two outward-focused (joy, anger) and two inward-focused emotions (pride, guilt) with one positive and one negative emotion per focus. All four emotions are well established in $\mathrm{OH}$ and have unique links to workrelevant constructs (Glomb, 2002; Hu \& Kaplan, 2014; Ilies, Peng, et al., 2013; Shockley et al., 2012).

In developing our hypotheses on the well-being outcomes, we built on the idea that specific affective (adversity and humor), cognitive (complexity and importance), and typicality characteristics would provide explanatory value in addition to the already established positive/negative dimensions. We specifically assumed that the dimensions would broadly improve the prediction of the daily well-being outcomes. However, we also studied potential unique and specific relationships between work event dimensions and specific outcomes in an exploratory fashion. Building on these ideas, we developed two sets of research objectives.

The first set of research objectives focused on the specific affective characteristics of work events (adversity and humor). These two dimensions differ from the general negativity 
dimension in CAPTION that describes general discomfort and from the general positivity dimension of CAPTION that includes broad affect like positivity, sensitivity, and warmth of the work event. Adversity refers specifically to situations that are tiresome and frustrating and is conceptually related to the disruption dimension in EST (Morgeson et al., 2015). Humor specifically describes situations creating laughter and amusement. Researchers in different areas (Cooper et al., 2018; Mesmer-Magnus et al., 2012; Robert \& Wilbanks, 2012) argued that humor is related to positive affect but also functionally distinct. In summary, we formulated the following hypotheses:

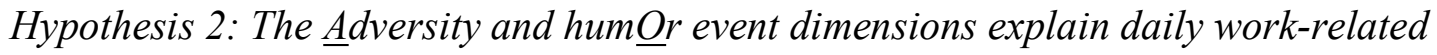
well-being beyond the Positivity/Negativity event dimensions.

Hypothesis 3: The Adversity event dimension is negatively related to daily work-related

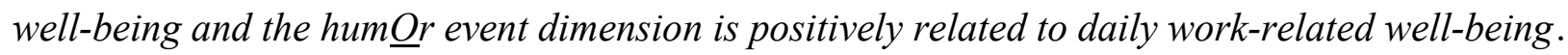

Based on organizational research arguing for situational strength and context explanations (Johns, 2006; Meyer et al., 2010; Morgeson et al., 2015), we also assumed that the non-affective dimensions would provide additional insights into daily well-being. Importance of work events has already been positively linked to well-being in form of goal-enhancing work events (Parker et al., 2020; Zohar et al., 2003) and in form of event criticality (Morgeson et al., 2015; Morgeson \& Derue, 2006). Typicality—or novelty in EST—has rarely been studied in event research but EST (Morgeson et al., 2015) offers theoretical arguments for event novelty to negatively affect well-being. The relevance of complexity for situations has already been shown in earlier research (Horton \& Griffin, 2017; Hunter et al., 2009; Tremblay et al., 2012). We specifically developed the following hypotheses: 
Hypothesis 4: The Complexity, Typicality, and Importance event dimensions explain daily work-related well-being beyond the Positivity/Negativity event dimensions.

Hypothesis 5: The Complexity, Typicality, and Importance event dimensions are positively related to daily work-related well-being.

\section{Study 1}

\section{Methods}

\section{Participants and Procedure}

The study used a diary design including five workdays with two measurement points per day and was formally approved by the institutional review board of the authors' university (ethical protocol number: ). Employees, who were interested in participating in the study, received a paper booklet including the informed consent, detailed instruction on how to fill in the booklet, a background questionnaire asking for demographic information, and the diary booklet including questionnaires for each of the five days. Participants filled in the demographic questionnaire the day before the diary week started. Starting with the following day, the participants filled in the diary for five consecutive workdays, twice a day (morning and directly after work).

The target population was a diverse population of employees in Germany and Belgium. Five hundred forty-four employees agreed to participate in the study and 243 of them sent their booklets back. One participant was excluded from the analyses because they did not fill in the diary part of the study. The remaining 242 employees filled in 9.74 out of a total of ten measurement points on average ${ }^{1}$. One-hundred fifty-three were female, 88 were male, and one

\footnotetext{
${ }^{1}$ To account for potential bias as a result of study attrition, we used inversed probability weighting using sampling weights. Using weights is a standard approach to control for biased samples when the study samples do not evenly represent the population (Thoemmes \& Ong, 2016). We did this analysis in two steps. First, we built a
} 
person did not indicate their gender. The participants were between 21 and 61 years old $(M=$ $38.48, S D=12.07)$. They had worked for their current organization for an average of 12.37 years $(S D=12.10)$, and $64.46 \%$ had a university education, $7.85 \%$ had a high-school degree, $20.66 \%$ had a middle school degree, and 6.61\% had followed basic school education (one person did not indicate their school degree). The sample included a broad range of professions (about 30 different professions in total). Most participants worked as administrators (24), human resource management professionals (23), kindergarten or school teachers (23), and sales representatives (21).

\section{Measures}

All questionnaires were available in Dutch and German. We used short scales to keep the participants' effort manageable like it is typically done in diary designs (Ohly et al., 2010).

Events classification (after work). After completing the workday, participants were asked to shortly describe all events of the workday in one or two sentences. To clarify for the participants what a work event is, we added a short description and examples before each event section. We defined work events as "all events that you have experience in connection with your work and that you consider important or relevant. This includes not only major events (e.g., promotion, conflicts in the workplace) but also minor incidents (e.g., praise from a superior or customer, computer program crashes)." The questionnaire offered space for up to five events per day and participants were instructed to add additional events on the backside of the questionnaire

logistic regression and predicted the response $(0 / 1)$ to each measurement point with person-level information collected in the pre-survey. We specifically predicted the responses to the measurement points with age, gender, education degree, tenure at the current company, and BIG 5 personality traits. From the logistical regression, we derived the probability weights indicating the conditional probability of a person with specific demographics and personality to respond to a measurement point. We inversed these scores and, thereby, give higher weights to respondents who are underrepresented in the sample. In a second step, we included the inversed probability weights in the multilevel SEM in lavaan. We found $R^{2}$ not to change up to three digits and we found no changes in estimates up to three digits. In summary, the results suggest that potential study attrition does not meaningfully affect the study results. 
if needed (two participants reported each one additional event). Overall, each employee described on average $3.15(S D=1.42)$ work events per day. The participants then rated each work event using items adopted from the literature (Parrigon et al., 2017). To keep the questionnaire as short as possible, we used four items for each of the seven dimensions of the original CAPTION taxonomy. We used items from the CAPTION-SF (CAPTION-Short Form, Parrigon et al., 2017) questionnaire and translated them into Dutch and German. Two native speakers translated each item independently and then resolved potential differences through discussion. An example item was: "Did you perceive the situation as frustrating?". The response scale ranged from 0 (very little or not at all) to 4 (extreme). In the Appendix, we provide examples of participants' work events described and rated according to the CAPTION-SF scale.

Positive and negative affect (morning and after work). We measured positive and negative affect in the morning as well as directly after work. To keep the number of items low, we applied an eight-item scale (Ebesutani et al., 2012) based on the Positive Affect Negative Affect Scale (PANAS, Watson et al., 1988). The response scale ranged from 0 (very little or not at all) to 4 (extreme).

Emotional exhaustion (after work). Emotional exhaustion was measured after work. We used the nine-item subscale for emotional exhaustion of the Utrecht Burnout Scale (Schaufeli, 1995) with a response scale from 0 (never) to 6 (all the time). An example item was: "Today I felt empty at the end of the working day".

\section{Analysis}

For all analyses, we used a multilevel structural equation modeling framework and the lavaan package in the R statistical computing environment (Rosseel, 2012). Following recommendations in the literature, we handled missing data using multiple imputations (Enders, 
2010; Graham et al., 2007). We specifically relied on the mice (van Buuren \& Oudshoorn, 2011) and semTools (Jorgensen et al., 2018) packages in R for these analyses and pooled the likelihood ratio statistics using the approach by $\mathrm{Li}$ et al. (1991). In line with recommendations in the literature, we ran 20 imputations (Graham et al., 2007). We began our analyses by running multilevel confirmatory factor analyses (CFA) to study the dimensionality of work events at the event- and the day-level and to test Hypothesis 1. We then used Anderson and Gerbing's (1988) two-step structural equation modeling approach to test the structural models for the study. The measurement model in the first step of the procedure expanded the multilevel CFA-model by adding emotional exhaustion and positive/negative affect. The structural models in the second step contrasted a basic model with effects of event positivity/negativity on the outcome variables at both levels of analysis with models with additional CAPTION dimensions to test our Hypotheses 2 to 5. In all models, we included positive/negative morning affect as control variables because morning affect relates to the perception of events during the workday (Casper et al., 2019). For model comparisons, we used difference tests and compared fit indices (Cheung \& Rensvold, 2001).

\section{Results}

\section{Multilevel Confirmatory Factor Analyses}

Hypothesis 1 suggested that a 7-dimensional model will show increased fit compared to a 2- or 4-dimensional model at the event- and day-level. To study this question, we compared four different CFA-models nesting either work events $(k=3,693)$ in persons $(N=242)$ or workdays $(k=1,172)$ in persons $(N=242)$. In Table 2 , we provide fit indices for all four CFA models at the event- and day-level. In interpreting this table, take into account that researchers commonly view comparative fit index $(\mathrm{CFI})>.90$, root-mean-square error of approximation $(\mathrm{RMSEA})<$ 
.09 , and standardized root-mean-square residual $(\mathrm{SRMR})<.07$ as evidence for satisfactory model fit (R. B. Kline, 2016). As shown in Table 2, the 2-factor and 4-factor models provided a model fit far removed from levels of fit commonly viewed as satisfactory in the literature. In contrast, the 7-factor models increased the model fit considerably. Hypothesis 1 was thus supported. To further improve the fit of our measure, we deleted the item per dimension with the lowest factorloadings on the original dimensions. For event negativity, all four items were loading equally well on the event negativity dimension but the item "despicable" showed high cross-loadings on the factor event adversity with modification indices $(\mathrm{mi})=358.29$ for the event in person nesting and $\mathrm{mi}=103.85$ for the day in person nesting. We thus deleted this item from the event negativity dimension. The resulting 3-items per factor solution showed a satisfactory model fit (see Table 2). Factor loadings and ICC(1) values for the 4-item and 3-item solution at the between- and within-person level are available as online supplementary material. Although ICC(1) typically tends to resemble the between-person factor loadings, it still gives additional information (Bliese et al., 2019). The ICC(1) values range from .13 to .44 at the event-level and from .24 to .62 at the day-level with "frustrating" and "academic" having the most extreme values, respectively. Overall, the ICC(1) values suggest that all items capture variance at both levels of analysis and thus support the need to use a multilevel modeling approach.

\section{Measurement Models}

For building the full measurement model, we expanded the final CFA-model at the daylevel (Model 4) by adding emotional exhaustion, positive/negative affect after work, and positive/negative affect in the morning (Model 5). Fit indices of the measurement model were satisfactory and are presented in Table 2 . 
Table 3 presents reliabilities at the between- and within-person level for Model 5. We estimated reliability using a CFA-based Cronbach's alpha to control for the multilevel structure of the data (Geldhof et al., 2014). Table 3 also presents the latent correlations of all latent variables at the between- and within-person level for Model 5. The correlations of some variables were considerable which is to be expected in this type of diary design. We specifically found three correlations of $r>.80$ at the between-person level (positive affect morning/after work, negative affect morning/after work, event negativity/negative affect after work). The high correlations suggest redundancy between the variables (T. Kline, 2005). However, it is intuitively expected that morning and after work affect are highly correlated.

\section{Structural Models}

Table 4 includes the model comparisons between the structural models testing Hypotheses 2 to 5 . Hypothesis 2 predicted that specific affective dimensions (adversity and humor) predict daily well-being beyond event positivity/negativity. As shown in Table 4, a model (Model 6b) that included effects of adversity and humor next to positivity/negativity on well-being had a better model fit than a model including positivity/negativity alone (Model 6a), $\Delta \chi^{2}(12)=132.22, p<.001$. These findings support Hypothesis 2 (for a full comparison of fit indices, see Table 4; for $R^{2}$, see Table 5).

Hypothesis 4 suggested that cognitive and typical event dimensions explain daily wellbeing beyond event positivity/negativity. As shown in Table 4, model comparisons indicated that a model including complexity, importance, and typicality next to positivity/negativity improved model fit, $\Delta \chi^{2}(18)=32.64, p=.018$. These findings support Hypothesis 4 (for a full comparison of fit indices, see Table 4; for $R^{2}$, see Table 5). However, the effects were overall relatively small (see Table 5). 
In a final step, we added paths from all seven CAPTION dimensions to well-being simultaneously (Model 6d) to test Hypotheses 3 and 5. As shown in Table 4, this full CAPTION model showed a better fit than all other models in Table 4. To answer Hypothesis 3, a more detailed examination of the effects in Table 5 indicated that the improvements in model fit from the specific affect dimensions primarily resulted from effects of adversity at the within-person level $(\gamma=.46, \gamma=-.27, \gamma=.40$ for emotional exhaustion, positive affect, and negative affect, respectively). Humor is only related to positive affect after work $(\gamma=.15)$. Hypothesis 3 is partwise supported.

Further examinations also revealed limited evidence for substantial effects of the three cognitive and typicality dimensions on the outcomes (see Table 5) suggesting that Hypothesis 5 could largely be declined. We specifically did not find any relations between cognitive/typical event dimensions at the between-person or within-person level except a small negative relation between typicality of work events and positive affect after work.

\section{Study 2}

In Study 2, we first cross-validated our findings regarding the factor structure of work events established in Study 1 using a new sample. We then extended our theoretical ideas (Hypotheses 2-5) regarding the link between work events and well-being from broad well-being indicators (emotional exhaustion, positive/negative affect after work in Study 1) to discrete emotions at work (joy, pride, anger, and guilt). As discrete emotions change quicker than general affect, we investigated them directly after the event occurred. To achieve these goals, we conducted an online study and used an experience sampling method (ESM) design to measure work events and discrete emotions. Thus in Study 2, we focused on the event-level as the withinperson level. 


\section{Methods}

The second study used an ESM design including two measurement points per day over ten consecutive workdays and was formally approved by the institutional review board of the authors' university as part of the same project as Study 1 (ethical protocol number: ----------). Employees who were interested in participating in this study provided their e-mail address and received a first e-mail giving information on the different parts of the research. Participants then received a first online survey, including informed consent and demographic questions. After the participants gave informed consent, they received two online surveys per day for two consecutive workweeks (ten workdays). Survey 1 was sent before noon (between 9:30 AM and 11:30 AM), survey 2 was sent in the afternoon (between 2:30 PM and 4:30 PM). Both surveys assessed whether a work event had occurred within the past hour and what emotions the participants felt at that moment. To avoid expectancy effects when receiving the two daily surveys, we randomized the time points within the time windows. Participants had two hours to fill in the surveys before they automatically expired.

The data collection targeted employees of diverse domains and professions in Belgium. Three hundred sixty-six employees agreed to participate but 29 did not fill in the informed consent and 42 did not fill in the diary part of the study. The remaining 295 participants (165 female, 129 male, one person did not indicate their gender) responded on average to 5.01 out of 20 online surveys ${ }^{2}$, were between 21 and 67 years old $(M=35.95, S D=11.30)$, and had worked on average 8.12 years $(S D=9.48)$ for their current organization. In this sample, $82.03 \%$ had a university degree, $7.12 \%$ had a high school degree, $8.14 \%$ had a middle school degree, $2.03 \%$

\footnotetext{
${ }^{2}$ To account for potential bias as a result of study attrition, we again used inversed probability weighting with age, gender, education degree, tenure at the current company, and HEXACO personality traits. Again, $R^{2}$ and estimates did not change up to three digits. In summary, these results suggest that study attrition did not meaningfully affect the study results.
} 
had a basic school education (two participants did not indicate their education level). The sample was composed of a broad range of professions with most participants working in engineering (34), health care (24), kindergarten or school teaching (24), consulting (21), and administration (21).

\section{Measures}

All questionnaires were available in Dutch and French. We again used shortened scales to reduce the effort for participants (Ohly et al., 2010).

Event classification. Participants were first asked to describe work events and then rate them on items derived from the CAPTION taxonomy using the same instructions as in Study 1. To diminish the daily effort for the participants, we reduced the CAPTION-SF scale to the three items derived from the reduced CAPTION model (Model 4) in Study 1.

Discrete emotions. For measuring discrete emotions after work, we extracted short scales for all four emotions from the literature. Anger was measure with the items "angry", "irritated", and "aggravated", joy was measured with "happy", "satisfied", and "joyful” (Van Kleef et al., 2006), pride was measured with “proud", “confident”, "successful” (Tracy \& Robins, 2007), and guilt was measured with "guilty", "ashamed”, "regretful” (Shaver et al., 1987).

\section{Analysis}

We used the same analytical approach as in Study 1.

\section{Results}

\section{Measurement Models}

We began by testing the reduced 7-factor multilevel CFA — established in Study 1—in the new sample $(k=1,587$ work events in $N=295$ employees, and $k=1,298$ workdays in $N=$ 295 employees). Results revealed satisfactory fit (see Table 6). Factor loadings and ICC(1) 
values for all CAPTION items at the between- and within-person level were similar to the values in Study 1 and are accessible as online supplementary material. Next, we added all four emotions to the CFA-model for the full measurement model (Model 8). This model again showed satisfactory fit (see Table 6).

Table 7 presents reliabilities and latent correlations of Model 8 at the between- and within-person level. The high correlations are again to be expected in this sort of ESM design. The anger/adversity correlation exceeds $r>.80$ and suggests redundancy at the between- and within-person level (T. Kline, 2005) similar to Study 1.

\section{Structural Models}

Table 8 shows the model comparisons between the structural models testing our Hypotheses 2 to 5. As shown in Table 8, we again found support for Hypothesis 2 suggesting that the specific affectivity dimensions adversity and humor predict well-being beyond positivity/negativity. The model including the two additional dimensions provided a better fit, $\Delta$ $\chi^{2}(16)=188.27, p<.001$.

We also again found support for Hypotheses 4. As shown in Table 8, the model including cognitive and typicality event dimensions beyond positivity/negativity showed a better model fit than the model including positivity/negativity alone, $\Delta \chi^{2}(24)=187.53, p<.001$.

In a final step, we ran a model that predicted emotions with all seven CAPTION dimensions simultaneously to test Hypotheses 3 and 5. This full CAPTION model showed a better fit than the previous models (see Table 8). Table 9 shows standardized estimates and $z$ values for all paths at the between- and within-person level for this full model.

As shown in Table 9, adversity had significant within-person effects on all four emotions $(\gamma=-.36, \gamma=-.19, \gamma=.72$, and $\gamma=.30$ for joy, pride, anger, and guilt, respectively). Humor only 
had an effect on the two positive emotions $(\gamma=.15$ and $\gamma=.12$ for joy and pride, respectively). Regarding Hypothesis 3, these findings suggest that adversity is a broad predictor of eventrelated emotions and humor only related to positive emotions.

Table 9 also indicated that complexity $(\gamma=.09$ for joy, and $\gamma=.18$ for pride) and importance $(\gamma=.15$ for joy, and $\gamma=.27$ for pride) were related to positive emotions at the withinperson level. These findings suggest that cognitive dimensions were primarily linked to positive event-related emotions and, thus, partwise support Hypothesis 5.

\section{Discussion}

Most existing work on work events and well-being has built on a two-dimensional view of the nature of work events with positive and negative events. The present study extends this existing literature on work events (Basch \& Fisher, 1998; Ohly \& Schmitt, 2015; Weiss \& Cropanzano, 1996) by integrating it with research on situation strength (Johns, 2006; Meyer et al., 2010), cognitive perspectives on events (Meyer et al., 2010; Morgeson et al., 2015), and broader perspectives on situation perceptions recently developed by personality psychologists (e.g., Parrigon et al., 2017). The result is an integrated multidimensional view of event perceptions. We studied the potential value of such an extended view and in particular the value of adding specific affective dimensions (adversity and humor) and cognitive and typicality dimensions (importance, complexity, and typicality) in two studies. Three key findings emerged from these empirical studies. First, we found that a multidimensional model improved model fit over the common positive/negative events framework at the event-, day-, and person-levels. Second, we found that accounting for additional affective and cognitive/typical event dimensions improved the explanation of daily well-being beyond the positive/negative event dimensions. The results specifically suggested that the addition of the specific affective dimensions improved 
model fit in both studies. The cognitive dimensions improved model fit particularly in Study 2 . Third, our results revealed specific patterns of relations between CAPTION dimensions and well-being indicators at the between- and within-person level. These findings are summarized in Table 10. At the within-person level, we especially found support for the idea that adversity is an important dimension that explains well-being outcomes beyond negative and positive event characteristics in both studies. Study 2 also provided evidence that more fine-grained discrete emotions are associated with complexity, importance, and typicality of events. Overall, negative and adverse events showed more and stronger links to well-being than positive/humorous or nonaffective event dimensions.

\section{Theoretical and Practical Implications}

One theoretical implication of this research is that a multidimensional perspective provides some useful benefits for linking work events and occupational health. Our empirical findings provide evidence that supports assumptions of earlier research like event system theory (e.g., Morgeson et al., 2015) suggesting that cognitive dimensions are important. We found that adversity and importance_- conceptually analog to the disruption and criticality dimensions in the EST framework - contributed to a better understanding of daily well-being at the betweenand at the within-person level. Our findings at the within-person level are arguably most interesting because the within-person level provides insights into fluctuations in daily work life and especially the degree to which situational variations can explain these fluctuations.

A second theoretical implication is that our study provides initial evidence for specific links between event dimensions and daily well-being. These effects suggest that some dimensions are broadly relevant, and some dimensions only predict specific types of daily wellbeing. Adversity was linked to all seven well-being outcomes. In contrast, humor was only a 
relevant predictor for positive well-being indicators and cognitive aspects of work events related to positive emotions (joy, pride) only, but did not contribute to negative aspects of well-being. For typicality we found, contrary to our expectations, a small positive relationship with anger and a small negative relationship with positive affect after work. We believe that these patterns provide a potential building block for future theory development. These specific links may also have practical implications because they can provide a better understanding of how employees react to certain types of events at work and can thus inform potential intervention strategies. For instance, our results suggest that encouraging humorous work events is associated with higher well-being. Earlier research has shown that a daily humor intervention increased happiness and decreased depression within one week (Wellenzohn et al., 2016). Likewise, our finding that cognitive aspects of events are linked to positive emotions suggests that small daily challenges and goals could directly strengthen well-being by increasing positive emotions at work.

Finally, the third implication of this work relates to our findings suggesting that negative and adverse events show more and stronger links to well-being than positive or humorous events. These findings are in line with earlier research documenting that bad is frequently stronger than good for predicting well-being outcomes at work (Bono et al., 2013; Eby et al., 2010; Gross et al., 2011; Zohar et al., 2003) Our findings are also in line with a broader stream of research suggesting that negative experiences are typically stronger than positive ones (Baumeister et al., 2001).

\section{Strengths and Limitations}

The present studies have several strengths. First, both studies are based on the elaborate diary and ESM designs with multiple measurement points per day. These designs enabled the participants to describe their events very shortly after they occurred and reduced hindsight bias. 
Second, both studies assessed work events with the full set of seven CAPTION dimensions as well as an overall set of seven different well-being indicators and thereby highlight the potential for future applications. The comprehensive assessment of events showed that CAPTION is a suitable measure for daily work events and enabled us to reduce the number of items per dimension to limit the load for participants in future diary and ESM designs. The broad assessment of well-being allowed us to get more detailed insight into the diverse event dimension/well-being link and, thus, serves as a basis for future research.

The studies have also several limitations. A limitation of Study 1 is the fact that we did not have objective data on when the participants filled in the surveys due to the paper/pencil design of the study. However, we instructed participants to fill in the survey at the requested time points and to indicate the weekday, date, and time when they answered the survey. Participants in this study had no incentive to not answer these questions truthfully. However, like with the other responses in both studies and in all survey research, we cannot rule out this possibility. Study 2 addressed this potential limitation by collecting digital time stamps on when participants filled in the survey.

A limitation of both studies is the fact that the research design was quite time-intensive because participants needed to fill in a relatively large number of questionnaires. However, we partly addressed this limitation by developing a shortened version of the CAPTION-SF with just three items for each dimension. The use of this measure could be feasible in a variety of future research settings. This being noted, researchers likely need to balance time consumption in their research against the benefits of a multidimensional perspective. From our data, it is also clear that the positive/negative taxonomy used in earlier research captures a considerable amount of variability in work event experiences. 


\section{Future Research}

For future research, a multidimensional perspective on work events may be useful to study relationships between events and well-being outcomes in more detail. For instance, our findings on affective well-being could be expanded to also study physical well-being in the future. Earlier research studied how work events relate to employees’ physical well-being, however, the results are inconclusive (Bono et al., 2013; Koopmann et al., 2016; Meier et al., 2014). A more detailed dimensionality of events may help to disentangle the effects of work events on physical well-being.

Overall, a multidimensional approach including specific affective dimensions, cognitive, and typicality dimensions offers more opportunities for researchers to select dimensions that are relevant for their specific research questions. For example, researchers interested in burnout could focus on the adversity event dimension. In contrast, researchers interested in performance and innovation can opt for cognitive dimensions such as complexity and importance.

\section{Conclusion}

In this article, our goal was to broaden perspectives on work events. Our findings suggest that a multidimensional perspective on measuring work events provides insights beyond earlier research focusing on a two-dimensional positive/negative framework on daily work events. The additional dimensions explain daily well-being and show unique relationship patterns with wellbeing outcomes at the within- and between-person level. We believe that these findings provide a building block for more fine-grained work event research within and beyond occupational health psychology. 


\section{References}

Anderson, J. C., \& Gerbing, D. W. (1988). Structural equation modeling in practice: A review and recommended two-step approach. Psychological Bulletin, 103(3), 411-423. https://doi.org/10.1037//0033-2909.103.3.411

Barclay, L. J., Skarlicki, D. P., \& Pugh, S. D. (2005). Exploring the role of emotions in injustice perceptions and retaliation. Journal of Applied Psychology, 90(4), 629-643. https://doi.org/10.1037/0021-9010.90.4.629

Basch, J., \& Fisher, C. D. (1998). Affective events-emotions matrix: A classification of work events and associated emotions. School of Business Discussion Papers, 65, 1-20.

Baumeister, R. F., Bratslavsky, E., \& Vohs, K. D. (2001). Bad is stronger than good. Review of General Psychology, 5, 323-370. https://doi.org/10.1037//1089-2680.5.4.323

Beehr, T. A., Jex, S. M., Stacy, B. A., \& Murray, M. A. (2000). Work stressors and coworker support as predictors of individual strain and job performance. Journal of Organizational Behavior, 21(4), 391-405. https://doi.org/10.1002/(SICI)10991379(200006)21:4<391::AID-JOB15>3.0.CO;2-9

Bledow, R., Schmitt, A., Frese, M., \& Kühnel, J. (2011). The affective shift model of work engagement. Journal of Applied Psychology, 96(6), 1246-1257. https://doi.org/10.1037/a0024532

Bliese, P. D., Maltarich, M. A., Hendricks, J. L., Hofmann, D. A., \& Adler, A. B. (2019). Improving the measurement of group-level constructs by optimizing between-group differentiation. Journal of Applied Psychology, 104(2), 293-302. https://doi.org/10.1037/ap10000349

Bono, J. E., Glomb, T., Shen, W., Kim, E., \& Koch, A. (2013). Building positive resources: 
Effects of positive events and positive reflection on work-stress and health. Academy of Management Journal, 56(6), 1601-1627. https://doi.org/10.5465/amj.2011.0272

Braukmann, J., Schmitt, A., Ďuranová, L., \& Ohly, S. (2018). Identifying ICT-related affective events across life domains and examining their unique relationships with employee recovery. Journal of Business and Psychology, 33(4), 529-544. https://doi.org/10.1007/s10869-017-9508-7

Brown, N. A., Neel, R., \& Sherman, R. A. (2015). Measuring the evolutionarily important goals of situations: Situational affordances for adaptive problems. Evolutionary Psychology, 13(3), 1-15. https://doi.org/10.1177/1474704915593662

Casper, A., Tremmel, S., \& Sonnentag, S. (2019). The power of affect: A three-wave panel study on reciprocal relationships between work events and affect at work. Journal of Occupational and Organizational Psychology, 92(2), 436-460. https://doi.org/10.1111/joop.12255

Chen, G., Bliese, P. D., \& Mathieu, J. E. (2005). Conceptual framework and statistical procedures for delineating and testing multilevel theories of homology. Organizational Research Methods, 8(4), 375-409. https://doi.org/10.1177/1094428105280056

Cheung, G. W., \& Rensvold, R. B. (2001). The effects of model parsimony and sampling error on the fit of structural equation models. Organizational Research Methods, 4(3), 236-264. https://doi.org/10.1177/109442810143004

Colquitt, J. A. (2001). On the dimensionality of organizational justice: A construct validation of a measure. Journal of Applied Psychology, 86(3), 386-400. https://doi.org/10.1037//00219010.86 .3 .386

Cooper, C. D., Kong, D. T., \& Crossley, C. D. (2018). Leaders humor as an interpersonal 
resource: Integrating three theoretical perspectives. Academy of Management Journal, 61(2), 769-796. https://doi.org/10.5465/amj.2014.0358

Curran, P. J., \& Bauer, D. J. (2012). The disaggregation of within-person and between-person effects in longitudinal models of change. Annual Review of Psychology, 62, 583-619. https://doi.org/10.1146/annurev.psych.093008.100356

Demerouti, E., \& Cropanzano, R. (2016). The buffering role of sportsmanship on the effects of daily negative events. European Journal of Work and Organizational Psychology, 26(2), 263-274. https://doi.org/10.1080/1359432X.2016.1257610

Diefendorff, J. M., Gabriel, A. S., \& Nolan, M. T. (2019). Emotion regulation in the context of customer mistreatment and felt affect: An event-based profile approach. Journal of Applied Psychology, 104(7), 965-983. https://doi.org/10.1037/ap10000389

Dyer, N. G., Hanges, P. J., \& Hall, R. J. (2005). Applying multilevel confirmatory factor analysis techniques to the study of leadership. Leadership Quarterly, 16(1), 149-167. https://doi.org/10.1016/j.leaqua.2004.09.009

Ebesutani, C., Regan, J., Smith, A., Reise, S., Higa-McMillan, C., \& Chorpita, B. F. (2012). The 10-item Positive and Negative Affect Schedule for children, child and parent shortened versions: Application of item response theory for more efficient assessment. Journal of Psychopathology and Behavioral Assessment, 34(2), 191-203. https://doi.org/10.1007/s10862-011-9273-2

Eby, L. T., Butts, M. M., Durley, J., \& Rose, B. (2010). Are bad experiences stronger than good ones in mentoring relationships? Evidence from the protégé and mentor perspective. Journal of Vocational Behavior, 77(1), 81-92. https://doi.org/10.1016/j.jvb.2010.02.010

Edwards, J. A., \& Templeton, A. (2005). The structure of perceived qualities of situations. 
European Journal of Social Psychology, 35(6), 705-723. https://doi.org/10.1002/ejsp.271

Ekman, P. (1993). Facial expression and emotion. American Psychologist, 48(4), 384-392.

Elfering, A., Grebner, S., Semmer, N. K., Kaiser-Freiburghaus, D., Ponte, S. L. Del, \& Witschi, I. (2005). Chronic job stressors and job control: Effects on event-related coping success and well-being. Journal of Occupational and Organizational Psychology, 78, 237-252. https://doi.org/10.1348/096317905X40088

Enders, C. K. (2010). Applied missing data analysis. Guilford.

Feldman Barrett, L., \& Russell, J. A. (1998). Independence and bipolarity in the structure of current affect. Journal of Personality and Social Psychology, 74(4), 967-984. https://doi.org/10.1037/0022-3514.74.4.967

Fifield, J., McQuillan, J., Armeli, S., Tennen, H., Reisine, S., \& Affleck, G. (2004). Chronic strain, daily work stress and pain among workers with rheumatoid arthritis: Does job stress make a bad day worse? Work and Stress, 18(4), 275-291. https://doi.org/10.1080/02678370412331324996

Fuller, J. A., Fisher, G. G., Stanton, J. M., Spitzmüller, C., Russell, S. S., \& Smith, P. C. (2003). A lengthy look at the daily grind: Time series analysis of events, mood, stress, and satisfaction. Journal of Applied Psychology, 88(6), 1019-1033. https://doi.org/10.1037/0021-9010.88.6.1019

Geldhof, G. J., Preacher, K. J., \& Zyphur, M. J. (2014). Reliability estimation in a multilevel confirmatory factor analysis framework. Psychological Methods, 19(1), 72-91. https://doi.org/10.1037/a0032138

Glomb, T. M. (2002). Workplace anger and aggression: Informing conceptual models with data from specific encounters. Journal of Occupational Health Psychology, 7(1), 20-36. 
https://doi.org/10.1037/1076-8998.7.1.20

Gooty, J., Gavin, M. B., Ashkanasy, N. M., \& Thomas, J. S. (2014). The wisdom of letting go and performance: The moderating role of emotional intelligence and discrete emotions. Journal of Occupational and Organizational Psychology, 87(2), 392-413. https://doi.org/10.1111/joop.12053

Graham, J. W., Olchowski, A. E., \& Gilreath, T. D. (2007). How many imputations are really needed? Some practical clarifications of multiple imputation theory. Prevention Science, 8(3), 206-213. https://doi.org/10.1007/s11121-007-0070-9

Grandey, A. A., Dickter, D. N., \& Sin, H. P. (2004). The customer is not always right: Customer aggression and emotion regulation of service employees. Journal of Organizational Behavior, 25(3), 397-418. https://doi.org/10.1002/job.252

Grandey, A. A., Tam, A. P., \& Brauburger, A. L. (2002). Affective states and traits in the workplace: Diary and survey data from young workers. Motivation and Emotion, 26(1), 31 55. https://doi.org/10.1023/a:1015142124306

Gross, S., Semmer, N. K., Meier, L. L., Kälin, W., Jacobshagen, N., \& Tschan, F. (2011). The effect of positive events at work on after-work fatigue: They matter most in face of adversity. Journal of Applied Psychology, 96(3), 654-664. https://doi.org/10.1037/a0022992

Hillebrandt, A., \& Barclay, L. J. (2017). Comparing integral and incidental emotions: Testing insights from emotions as social information theory and attribution theory. Journal of Applied Psychology, 102(5), 732-752. https://doi.org/https://doi.org/10.1037/ap10000174

Hoobler, J. M., Rospenda, K. M., Lemmon, G., \& Rosa, J. A. (2010a). A within-subject longitudinal study of the effects of positive job experiences and generalized workplace 
harassment on well-being. Journal of Occupational Health Psychology, 15(4), 434-451. https://doi.org/10.1037/a0021000

Hoobler, J. M., Rospenda, K. M., Lemmon, G., \& Rosa, J. A. (2010b). A within-subject longitudinal study of the effects of positive job experiences and generalized workplace harassment on well-being. Journal of Occupational Health Psychology, 15, 434-451. https://doi.org/10.1037/a0021000

Horstmann, K. T., Rauthmann, J. F., \& Sherman, R. A. (2018). Measurement of situational influences. In V. Zeigler-Hill \& T. K. Shackelford (Eds.), The SAGE Handbook of Personality and Individual Differences (pp. 465-484). SAGE Publications.

Horton, K. E., \& Griffin, M. A. (2017). Identification complexity and conflict: How multiple identifications affect conflict across functional boundaries. European Journal of Work and Organizational Psychology, 26(2), 286-298.

https://doi.org/10.1080/1359432X.2016.1259215

Hu, X., \& Kaplan, S. A. (2014). Is “feeling good” good enough? Differentiating discrete positive emotions at work. Journal of Organizational Behavior, 36(1), 39-58. https://doi.org/https://doi.org/10.1002/job.1941

Hunter, S. T., Bedell-avers, K. E., \& Mumford, M. D. (2009). Impact of situational framing and complexity on charismatic, ideological and pragmatic leaders: Investigation using a computer simulation. Leadership Quarterly, 20(3), 383-404. https://doi.org/10.1016/j.leaqua.2009.03.007

Ilies, R., Johnson, M. D., Judge, T. A., \& Keeney, J. (2011). A within-individual study of interpersonal conflict as a work stressor: Dispositional and situational moderators. Journal of Organizational Behavior, 64, 44-64. https://doi.org/10.1002/job.677 
Ilies, R., Keeney, J., \& Goh, Z. W. (2013). Capitalising on positive work events by sharing them at home. Applied Psychology, 64(3), 578-598. https://doi.org/10.1111/apps.12022

Ilies, R., Keeney, J., \& Scott, B. A. (2011). Work-family interpersonal capitalization: Sharing positive work events at home. Organizational Behavior and Human Decision Processes, 114(2), 115-126. https://doi.org/10.1016/j.obhdp.2010.10.008

Ilies, R., Peng, A. C., Savani, K., \& Dimotakis, N. (2013). Guilty and helpful: An emotion-based reparatory model of voluntary work behavior. Journal of Applied Psychology, 98(6), 10511059. https://doi.org/10.1037/a0034162

Johns, G. (2006). The essencial impact of context on organizational behavior. Academy of Management Review, 31(2), 386-408. https://doi.org/10.5465/amr.2006.20208687

Jorgensen, T. D., Pornprasertmanit, S., Schoemann, A. M., Rosseel, Y., Miller, P., Quick, C., \& Garnier-Villarreal, M. (2018). semTools: Useful tools for structural equation modeling. $R$ Package Version 0.5-1.

Katz, D., \& Kahn, R. L. (1978). The social psychology of organizations (2nd ed., Issue 4). Wiley. https://doi.org/10.1093/sf/57.4.1413

Kline, R. B. (2016). Principles and practice of structural equation modeling. The Guilford Press. Kline, T. (2005). Psychological Testing: A Practical Approach to Design and Evaluation. SAGE. https://doi.org/10.4135/9781483385693

Koopmann, J., Lanaj, K., Bono, J. E., \& Campana, K. (2016). Daily shifts in regulatory focus: The influence of work events and implications for employee well-being. Journal of Organisational Behavior, 37(8), 1293-1316. https://doi.org/10.1002/job.2105

Kuba, K., \& Scheibe, S. (2017). Let it be and keep on going! Acceptance and daily occupational well-being in relation to negative work events. Journal of Occupational Health Psychology, 
22(1), 59-70. https://doi.org/10.1037/a0040149

Li, K.-H., Meng, X.-L., Raghunathan, T. E., \& Rubin, D. B. (1991). Significance levels from repeated p-values with multiply-imputed data. Statistica Sinica, 1(1), 65-92. https://www.jstor.org/stable/24303994

Maslach, C., Schaufeli, W. B., \& Leiter, M. P. (2001). Job burnout. Annual Review of Psychology, 52, 397-422. https://doi.org/10.1146/annurev.psych.52.1.397

Matta, F. K., Erol-Korkmaz, H. T., Johnson, R. E., \& Biçaksiz, P. (2014). Significant work events and counterproductive work behavior: The role of fairness, emotions, and emotion regulation. Journal of Organisational Behavior, 35(7), 920-944. https://doi.org/10.1002/job

Meier, L. L., Semmer, N. K., \& Gross, S. (2014). The effect of conflict at work on well-being: Depressive symptoms as a vulnerability factor. Work \& Stress, 28(1), 31-48. https://doi.org/10.1080/02678373.2013.876691

Mesmer-Magnus, J., Glew, D. J., \& Viswesvaran, C. (2012). A meta-analysis of positive humor in the workplace. Journal of Managerial Psychology, 27(2), 155-190. https://doi.org/10.1108/02683941211199554

Meyer, R. D., Dalal, R. S., \& Hermida, R. (2010). A review and synthesis of situational strength in the organizational sciences. Journal of Management, 36(1), 121-140. https://doi.org/10.1177/0149206309349309

Mignonac, K., \& Herrbach, O. (2004). Linking work events, affective states, and attitudes: An empirical study of managers' emotions. Journal of Business and Psychology, 19, 221-240. https://doi.org/10.1007/s10869-004-0549-3

Miner, A. G., Glomb, T. M., \& Hulin, C. (2005). Experience sampling mood and its correlates at work. Journal of Occupational and Organizational Psychology, 78(2), 171-193. 
https://doi.org/10.1348/096317905X40105

Mischel, W., \& Shoda, Y. (1995). A Cognitive-Affective System Theory of personality: Reconceptualizing situations, dispositions, dynamics, and invariance in personality structure. Psychological Review, 102(2), 246-268. https://doi.org/10.1037/0033$295 \times .102 .2 .246$

Moore, S., Grunberg, L., \& Greenberg, E. (2004). Repeated downsizing contact: The effects of similar and dissimilar layoff experiences on work and well-being outcomes. Journal of Occupational Health Psychology, 9(3), 247-257. https://doi.org/10.1037/1076-8998.9.3.247

Morgeson, F. P., \& Derue, D. S. (2006). Event criticality, urgency, and duration: Understanding how events disrupt teams and influence team leader intervention. Leadership Quarterly, 17(3), 271-287. https://doi.org/10.1016/j.leaqua.2006.02.006

Morgeson, F. P., Mitchell, T. R., \& Liu, D. (2015). Event system theory: An event-oriented approach to the organizational sciences. Academy of Management Review, 40(4), 515-537. https://doi.org/10.5465/amr.2012.0099

Ohly, S., \& Schmitt, A. (2015). What makes us enthusiastic, angry, feeling at rest or worried? Development and validation of an affective work events taxonomy using concept mapping methodology. Journal of Business and Psychology, 30(1), 15-35. https://doi.org/10.1007/s10869-013-9328-3

Ohly, S., Sonnentag, S., Niessen, C., \& Zapf, D. (2010). Diary studies in organizational research: An introduction and some practical recommendations. Journal of Personnel Psychology, 9(2), 79-93. https://doi.org/10.1027/1866-5888/a000009

Parker, S. L., Sonnentag, S., Jimmieson, N. L., \& Newton, C. J. (2020). Relaxation during the evening and next-morning energy: The role of hassles, uplifts, and heart rate variability 
during work. Journal of Occupational Health Psychology, 25(2), 83-98. https://doi.org/10.1037/ocp0000155

Parrigon, S., Woo, S. E., Tay, L., \& Wang, T. (2017). CAPTION-ing the situation: A lexicallyderived taxonomy of psychological situation characteristics. Journal of Personality and Social Psychology, 112(4), 642-681. https://doi.org/10.1037/pspp0000111

Paterson, J. M., \& Cary, J. (2002). Organizational justice, change anxiety, and acceptance of downsizing: Preliminary tests of an AET-based model. Motivation and Emotion, 26(1), 83103.

Pervin, L. A. (1978). Definitions, measurements, and classifications of stimuli, situations, and environments. Human Ecology, 6(1), 71-105. https://doi.org/10.1007/bf00888567

Potter, P. T., Smith, B. W., Strobel, K. R., \& Zautra, A. J. (2002). Interpersonal workplace stressors and well-being: A multi-wave study of employees with and without arthritis. Journal of Applied Psychology, 87(4), 789-796. https://doi.org/10.1037/00219010.87.4.789

Rauthmann, J. F., Gallardo-Pujol, D., Guillaume, E. M., Todd, E., Nave, C. S., Sherman, R. A., Ziegler, M., Jones, A. B., \& Funder, D. C. (2014). The situational eight DIAMONDS: A taxonomy of major dimensions of situation characteristics. Journal of Personality and Social Psychology, 107(4), 677-718. https://doi.org/10.1037/a0037250

Rauthmann, J. F., Horstmann, K. T., \& Sherman, R. A. (2019). The psychological characteristics of situations: Towards an integrated taxonomy. In J. F. Rauthmann, R. A. Sherman, \& D. C. Funder (Eds.), The Oxford Handbook of Psychological Situations. Oxford University Press. Rauthmann, J. F., Sherman, R. A., \& Funder, D. C. (2015). Principles of situation research: Towards a better understanding of psychological situations. European Journal of 
Personality, 29(3), 363-381. https://doi.org/10.1002/per.1994

Rentsch, J. R. (1990). Climate and culture: Interaction and qualitative differences in organisational meanings. Journal of Applied Psychology, 75(6), 668-681. https://doi.org/10.1037//0021-9010.75.6.668

Rescher, N. (1962). The revolt against process. The Journal of Philosophy, 59(15), 410-420. https://doi.org/10.2307/2022958

Robert, C., \& Wilbanks, J. E. (2012). The wheel model of humor: Humor events and affect in organizations. Human Relations, 65(9), 1071-1099. https://doi.org/10.1177/0018726711433133

Roesch, S. C., Aldridge, A. A., Stocking, S. N., Villodas, F., Leung, Q., Bartley, C. E., \& Black, L. J. (2010). Multilevel factor analysis and structural equation modeling of daily diary coping data: Modeling trait and state variation. Multivariate Behavioral Research, 45(5), 767-789. https://doi.org/10.1080/00273171.2010.519276

Rosseel, Y. (2012). lavaan: An R package for structural equation modeling. Journal of Statistical Software, 48(2), 1-36. http://www.jstatsoft.org/v48/i02/

Rothbard, N. P., \& Wilk, L. S. (2011). Waking up on the right or wrong side of the bed: Start-ofthe-workday mood, work events, employee affect, and performance. Academy of Management Journal, 54(5), 959-980. https://doi.org/10.5465/amj.2007.0056

Rueff Lopes, R., Navarro, J., Caetano, A., \& Silva, A. J. (2017). Forecasting the influence of customer-related micro-events on employees ' emotional, attitudinal and physiological responses. European Journal of Work and Organizational Psychology, 26(6), 779-797. https://doi.org/10.1080/1359432X.2017.1360286

Rupp, D. E., \& Spencer, S. (2006). When customers lash out: The effects of customer 
interactional injustice on emotional labor and the mediating role of discrete emotions. Journal of Applied Psychology, 91(4), 971-978. https://doi.org/10.1037/00219010.91.4.971

Schaufeli, W. B. (1995). The evaluation of a burnout workshop for community nurses. Journal of Health and Human Services Administration, 18, 11-30. https://doi.org/10.2307/25780843

Shaver, P., Schwartz, J., Kirson, D., Connor, G. O., Campos, J., Darley, J., Goldberg, L., Gollob, H., Goodman, G., Harter, S., Rosenberg, S., \& Smith, C. (1987). Emotion knowledge: Further exploration of a prototype approach. Journal of Personality and Social Psychology, 52(6), 1061-1086. https://doi.org/10.1037/0022-3514.52.6.1061

Shockley, K. M., Ispas, D., Rossi, M. E., \& Levine, E. L. (2012). A meta-analytic investigation of the relationship between state affect, discrete emotions, and job performance. Human Performance, 25(5), 377-411. https://doi.org/10.1080/08959285.2012.721832

Sonnentag, S. (2017). A task-level perspective on work engagement: A new approach that helps to differentiate the concepts of engagement and burnout. Burnout Research, 5, 12-20. https://doi.org/10.1016/j.burn.2017.04.001

Spencer, S., \& Rupp, D. E. (2009). Angry, guilty, and conflicted: Injustice toward coworkers heightens emotional labor through cognitive and emotional mechanisms. Journal of Applied Psychology, 94(2), 429-444. https://doi.org/10.1037/a0013804

Thoemmes, F., \& Ong, A. D. (2016). A primer on inverse probability of treatment weighting and marginal structural models. Emerging Adulthood, 4(1), 40-59. https://doi.org/10.1177/2167696815621645

Todorova, G., Bear, J. B., \& Weingart, L. R. (2014). Can conflict be energizing ? A study of task conflict, positive emotions, and job satisfaction. Journal of Applied Psychology, 99(3), 451- 
467. https://doi.org/10.1037/a0035134

Tracy, J. L., \& Robins, R. W. (2007). The psychological structure of pride: A tale of two facets. Journal of Personality and Social Psychology, 92(3), 506-525.

https://doi.org/10.1037/0022-3514.92.3.506

Tremblay, S., Vachon, F., Lafond, D., \& Kramer, C. (2012). Dealing with task interruptions in complex dynamic environments: Are two heads better than one ? Human Performance, 54(1), 70-83. https://doi.org/10.1177/0018720811424896

van Buuren, S., \& Oudshoorn, C. G. M. (2011). MICE: Multivariate imputation by chained equations in R. Journal of Statistical Software, 45(3), 1-67. https://doi.org/10.18637/jss.v045.i03

Van Kleef, G. A., De Dreu, C. K. W., Pietroni, D., \& Manstead, A. S. R. (2006). Power and emotion in negotiation: Power moderates the interpersonal effects of anger and happiness on concession making. European Journal of Social Psychology, 36(4), 557-581. https://doi.org/10.1002/ejsp.320

Volmer, J., Niessen, C., Binnewies, C., \& Sonnentag, S. (2012). Do social conflicts with customers at work encroach upon our private lives? A diary study. Journal of Occupational Health Psychology, 17(3), 304-315. https://doi.org/10.1037/a0028454

Wang, N., Zhu, J., Dormann, C., Song, Z., \& Bakker, A. B. (2019). The daily motivators: Positive work events, psychological needs satisfaction, and work engagement. Applied Psychology-An International Review, 69(2), 508-537. https://doi.org/10.1111/apps.12182 Watson, D., Clark, L. A., \& Tellegan, A. (1988). Development and validation of brief measures of positive and negative affect: The PANAS scales Worksheet 3.1 PANAS Schedule Questionnaire. Journal of Personality and Social Psychology, 54(6), 1063-1070. 
Weiss, H. M., \& Cropanzano, R. (1996). Affective events theory: A theoretical discussion of the structure, causes and consequences of affective experiences at work. In B. M. Staw \& L. L. Cummings (Eds.), Research in organizational behavior: An annual series of analytical essays and critical reviews (Vol. 18, pp. 1-74). JAI Press.

Weiss, H. M., Suckow, K., \& Cropanzano, R. (1999). Effects of justice conditions on discrete emotions. Journal of Applied Psychology, 84(5), 786-794. https://doi.org/10.1037/00219010.84 .5 .786

Wellenzohn, S., Proyer, R. T., \& Ruch, W. (2016). How do positive psychology interventions work? A short-term placebo-controlled humor-based study on the role of the time focus. Personality and Individual Differences, 96, 1-6. https://doi.org/10.1016/j.paid.2016.02.056

Ziegler, M., Horstmann, K. T., \& Ziegler, J. (2019). Personality in situations: Going beyond the OCEAN and introducing the Situation Five. Psychological Assessment, 31(4), 567-580. https://doi.org/10.1037/pas0000654

Zohar, D. (1999). When things go wrong: The effect of daily work hassles on effort, exertion and negative mood. Journal of Occupational and Organizational Psychology, 72(3), 265-283. https://doi.org/10.1348/096317999166671

Zohar, D., Epstein, R., \& Tzischinski, O. (2003). Effects of energy availability on immediate and delayed emotional reactions to work events. Journal of Applied Psychology, 88(6), 10821093. https://doi.org/10.1037/0021-9010.88.6.1082 
Table 1

Overview of Studies on Work Events and Well-being at Work

\begin{tabular}{|c|c|c|c|c|}
\hline Authors & $\begin{array}{l}\text { Sample, design, and } \\
\text { analyses }\end{array}$ & Measure of work events & $\begin{array}{l}\text { Measure of } \\
\text { well-being }\end{array}$ & Main findings \\
\hline $\begin{array}{l}\text { Basch and Fisher } \\
\text { (1998) }\end{array}$ & $\begin{array}{l}N=101 \text { (hotel } \\
\text { employees) } \\
\text { Retrospective survey } \\
\text { Qualitative data analysis }\end{array}$ & Work event (description) & $\begin{array}{l}\text { Emotions (affection, } \\
\text { pleasure, happiness, pride, } \\
\text { optimism, enthusiasm, } \\
\text { frustration, anger, disgust, } \\
\text { unhappiness, } \\
\text { disappointment, } \\
\text { embarrassment, worry, } \\
\text { relief, fear, hurt, bitterness, } \\
\text { annoyance, and } \\
\text { sadness) }\end{array}$ & $\begin{array}{l}\text { 1) Work events were categorized into } 14 \text { positive } \\
\text { event categories that predicted positive emotions } \\
\text { 2) Work events were categorized into } 13 \text { negative } \\
\text { event categories that predicted negative emotions } \\
\text { 3) The same event category instigated different } \\
\text { emotional reactions in different people }\end{array}$ \\
\hline $\begin{array}{l}\text { Beehr et al., } \\
(2000)\end{array}$ & $\begin{array}{l}N=198 \text { (bookdealers) } \\
\text { Retrospective survey } \\
\text { Regression analysis }\end{array}$ & $\begin{array}{l}\text { List of } 24 \text { occupation-specific } \\
\text { stressful events (occurrence) }\end{array}$ & $\begin{array}{l}\text { Depression } \\
\text { Frustration }\end{array}$ & $\begin{array}{l}\text { 1) Stressful events increased depression } \\
\text { 2) There was no relationship between stressful events } \\
\text { and frustration }\end{array}$ \\
\hline $\begin{array}{l}\text { Bledow et al. } \\
(2011)\end{array}$ & $\begin{array}{l}N=55 \text { (software } \\
\text { developers) } \\
\text { ESM 2x per day } \\
\text { HLM }\end{array}$ & $\begin{array}{l}\text { Negative events (frequency) } \\
\text { Positive events (frequency) } \\
\text { List including } \\
3 \text { positive events }+ \\
3 \text { negative events }+ \\
\text { additional events }\end{array}$ & $\begin{array}{l}\text { Positive affect } \\
\text { Negative affect } \\
\text { Work engagement }\end{array}$ & $\begin{array}{l}\text { 1) Negative events decreased work engagement } \\
\text { (mediated by negative affect) } \\
\text { 2) Positive events increased work engagement } \\
\text { (mediated by positive affect) }\end{array}$ \\
\hline Bono et al. (2013) & $\begin{array}{l}N=61 \text { (health care } \\
\text { professions) } \\
\text { ESM 4x per day }(15 \\
\text { workdays) } \\
\text { HLM }\end{array}$ & $\begin{array}{l}\text { Negative events (frequency) } \\
\text { Positive events (frequency) } \\
\text { Work-family-conflict } \\
\text { (frequency) } \\
\text { Every } 2 \text { hours: list including } \\
\text { events of all } 3 \text { types }\end{array}$ & $\begin{array}{l}\text { Systolic blood pressure } \\
\text { Perceived strain }\end{array}$ & $\begin{array}{l}\text { 1) Positive events decreased perceived strain } \\
\text { 2) Negative events increased perceived strain } \\
\text { 3) Work-family-conflict increased perceived strain } \\
\text { 4) No relation between positive events and blood } \\
\text { pressure } \\
\text { 5) Negative events increased blood pressure } \\
\text { 6) Work-family-conflict increased blood pressure }\end{array}$ \\
\hline
\end{tabular}


Table 1 (continued)

Overview of Studies on Work Events and Well-being at Work

\begin{tabular}{|c|c|c|c|c|}
\hline Authors & $\begin{array}{l}\text { Sample, design, and } \\
\text { analyses }\end{array}$ & Measure of work events & $\begin{array}{l}\text { Measure of } \\
\text { well-being }\end{array}$ & Main findings \\
\hline $\begin{array}{l}\text { Braukmann et al. } \\
\text { (2018) }\end{array}$ & $\begin{array}{l}N=154 \text { (different } \\
\text { industries) } \\
\text { Diary } 3 \mathrm{x} \text { per day on } \\
\text { weekdays, } 2 \mathrm{x} \text { per day on } \\
\text { weekend days ( } 8 \\
\text { consecutive days) } \\
\text { HLM }\end{array}$ & $\begin{array}{l}\text { Positive ICT events (occurrence) } \\
\text { Negative ICT events } \\
\text { (occurrence) } \\
\text { List of } 2 \text { positive and } 3 \text { negative } \\
\text { ICT event clusters }\end{array}$ & $\begin{array}{l}\text { Detachment from work } \\
\text { Quality of sleep }\end{array}$ & $\begin{array}{l}\text { 1) Negative ICT events partwise decrease work } \\
\text { detachment (relation with e-mails and continue work } \\
\text { task, no relation with work calls) } \\
\text { 2) Negative ICT events partwise sleep quality } \\
\text { detachment (relation with e-mails and work calls, no } \\
\text { relation with continue work task) } \\
\text { 3) Positive ICT events decrease work detachment } \\
\text { 4) No relation between positive ICT events and sleep } \\
\text { quality }\end{array}$ \\
\hline $\begin{array}{l}\text { Casper et al. } \\
(2019)\end{array}$ & $\begin{array}{l}N(\text { Time } 1)=1,039 ; \\
N(\text { Time } 2)=849 ; \\
N(\text { Time } 3)=815 \\
\text { 3-wave longitudinal } \\
\text { study } \\
\text { Path modeling }\end{array}$ & $\begin{array}{l}\text { Positive interpersonal work } \\
\text { events (PIWE) } \\
\text { Positive task-related work } \\
\text { events (PTWE) } \\
\text { Negative interpersonal work } \\
\text { events (NIWE) } \\
\text { Negative task-related work } \\
\text { events (NTWE) }\end{array}$ & $\begin{array}{l}\text { Positive affect } \\
\text { Negative affect }\end{array}$ & $\begin{array}{l}\text { 1) Positive affect increased PIWE from } T 1 \text { to } T 2 \text { and } \\
\text { from } T 2 \text { to } T 3 \\
\text { 2) Positive affect increased PTWE from } T 1 \text { to } T 2 \text { and } \\
\text { from } T 2 \text { to } T 3 \\
\text { 3) Negative affect increased NIWE from } T 1 \text { to } T 2 \\
\text { and from } T 2 \text { to } T 3 \\
\text { 4) Negative affect increased NTWE from } T 1 \text { to } T 2 \\
\text { and from } T 2 \text { to } T 3 \\
\text { 5) NTWE increased negative affect from } T 2 \text { to } T 3\end{array}$ \\
\hline $\begin{array}{l}\text { Demerouti and } \\
\text { Cropanzano } \\
(2016)\end{array}$ & $\begin{array}{l}N=112 \text { (different } \\
\text { professions) } \\
\text { Diary design } 2 x \text { per day } \\
\text { (3 days) } \\
\text { HLM }\end{array}$ & $\begin{array}{l}\text { Negative events (intensity) } \\
\text { Description of a negative work } \\
\text { event that day }\end{array}$ & $\begin{array}{l}\text { Positive affect } \\
\text { Work engagement }\end{array}$ & $\begin{array}{l}\text { 1) Negative events decreased positive affect } \\
\text { 2) Negative events decreased work engagement } \\
\text { 3) No relation between negative events and positive } \\
\text { affect and work engagement the following day }\end{array}$ \\
\hline $\begin{array}{l}\text { Diefendorff et al. } \\
\text { (2019) }\end{array}$ & $\begin{array}{l}N=250 \text { (call center } \\
\text { service) } \\
\text { ESM ( } 30 \text { surveys over } 10 \\
\text { workdays) } \\
\text { Multilevel path analysis }\end{array}$ & Customer incivility (intensity) & $\begin{array}{l}\text { Positive affect } \\
\text { Negative affect } \\
\text { Emotional exhaustion } \\
\text { Psychological vitality }\end{array}$ & $\begin{array}{l}\text { 1) Customer incivility decreases positive affect } \\
\text { 2) Customer incivility increases negative affect } \\
\text { 3) Customer incivility increases emotional exhaustion } \\
\text { via affect and emotion regulation } \\
\text { 4) No relation between customer incivility and } \\
\text { psychological vitality }\end{array}$ \\
\hline
\end{tabular}


Table 1 (continued)

Overview of Studies on Work Events and Well-being at Work

\begin{tabular}{|c|c|c|c|c|}
\hline Authors & $\begin{array}{l}\text { Sample, design, and } \\
\text { analyses }\end{array}$ & Measure of work events & $\begin{array}{l}\text { Measure of } \\
\text { well-being }\end{array}$ & Main findings \\
\hline $\begin{array}{l}\text { Elfering et al. } \\
(2005)\end{array}$ & $\begin{array}{l}N=23 \text { (counselling } \\
\text { agency employees) } \\
\text { Diary, event-based ( } 7 \\
\text { days) } \\
\text { HLM }\end{array}$ & $\begin{array}{l}\text { Stressful events (stressfulness, } \\
\text { controllability) }\end{array}$ & Well-being (mood) & $\begin{array}{l}\text { 1) Stressfulness of events decreased well-being } \\
\text { 2) Controllability of events increased well-being }\end{array}$ \\
\hline $\begin{array}{l}\text { Fifield et al. } \\
(2004)\end{array}$ & $\begin{array}{l}N=27 \text { (working } \\
\text { rheumatoid arthritis } \\
\text { patients) } \\
\text { Diary 3x per day ( } 20 \\
\text { workdays) } \\
\text { HLM }\end{array}$ & $\begin{array}{l}\text { List of } 86 \text { undesirable work } \\
\text { events (frequency) }\end{array}$ & $\begin{array}{l}\text { Negative mood } \\
\text { Physical pain }\end{array}$ & $\begin{array}{l}\text { 1) Undesirable work events in the morning increased } \\
\text { negative mood at midday } \\
\text { 2) Undesirable work events in the morning increased } \\
\text { physical pain at midday }\end{array}$ \\
\hline $\begin{array}{l}\text { Fuller et al. } \\
(2003)\end{array}$ & $\begin{array}{l}N=14 \text { (administrative } \\
\text { and classified staff) } \\
\text { ESM } 1 x \text { per day } \\
(14-18 \text { weeks) } \\
\text { Transfer Function } \\
\text { Analysis }\end{array}$ & $\begin{array}{l}\text { Stressful events (intensity) } \\
2 \text { open questions on stressful } \\
\text { events } \\
\text { Word-count method }\end{array}$ & $\begin{array}{l}\text { Job satisfaction } \\
\text { Perceived strain }\end{array}$ & $\begin{array}{l}\text { 1) Intensity of the stressful event increased strain the } \\
\text { same day and decreased strain the following day } \\
\text { 2) Intensity of the stressful event decreased job } \\
\text { satisfaction the same day and increased job } \\
\text { satisfaction the following day (mediated by perceived } \\
\text { strain) }\end{array}$ \\
\hline $\begin{array}{l}\text { Grandey et al., } \\
(2002)\end{array}$ & $\begin{array}{l}N=36 \text { (part-time } \\
\text { working students) } \\
\text { Diary, event-based ( } 2 \\
\text { workweeks) } \\
\text { HLM }\end{array}$ & $\begin{array}{l}\text { Work events that caused strong } \\
\text { feelings of love, happiness, } \\
\text { anger, sadness, and fear } \\
\text { (average intensity, intensity) }\end{array}$ & $\begin{array}{l}\text { Positive affect (trait) } \\
\text { Negative affect (trait) } \\
\text { Job satisfaction } \\
\text { Turnover intention }\end{array}$ & $\begin{array}{l}\text { 1) PA marginally increased positive emotional events } \\
\text { 2) NA increased negative emotional events } \\
\text { 3) There was no relation between positive emotional } \\
\text { events and job satisfaction or turnover intention } \\
\text { 4) There was no relation between negative emotional } \\
\text { events and job satisfaction } \\
\text { 5) Negative emotional events (esp. sadness) increased } \\
\text { turnover intention (only for average intensity, not for } \\
\text { intensity) } \\
\text { 6) Results were similar for average intensity and } \\
\text { intensity of emotional events }\end{array}$ \\
\hline
\end{tabular}


Table 1 (continued)

Overview of Studies on Work Events and Well-being at Work

\begin{tabular}{|c|c|c|c|c|}
\hline Authors & $\begin{array}{l}\text { Sample, design, and } \\
\text { analyses }\end{array}$ & Measure of work events & $\begin{array}{l}\text { Measure of } \\
\text { well-being }\end{array}$ & Main findings \\
\hline $\begin{array}{l}\text { Grandey et al. } \\
(2004)\end{array}$ & $\begin{array}{l}N=198 \text { (call center } \\
\text { employees) } \\
\text { Retrospective survey } \\
\text { Path modeling }\end{array}$ & $\begin{array}{l}\text { Customer verbal aggression } \\
\text { calls (frequency, stress } \\
\text { appraisal) }\end{array}$ & $\begin{array}{l}\text { Emotional exhaustion } \\
\text { Absence days }\end{array}$ & $\begin{array}{l}\text { 1) Frequency of customer verbal aggression } \\
\text { increased emotional exhaustion } \\
\text { 2) Stress appraisal of customer verbal aggression } \\
\text { increased emotional exhaustion } \\
\text { 3) Frequency of customer verbal aggression was } \\
\text { unrelated to absence days } \\
\text { 4) Stress appraisal of customer verbal aggression } \\
\text { increased absence days }\end{array}$ \\
\hline $\begin{array}{l}\text { Gross et al. } \\
(2011)\end{array}$ & $\begin{array}{l}N=76 \text { (government } \\
\text { agents) } \\
3 \text {-waves longitudinal } \\
\text { study } \\
\text { Event-based diary design } \\
3 \times 2 \text { working days (in a } \\
\text { range of } 6 \text { months) } \\
\text { HLM }\end{array}$ & $\begin{array}{l}\text { Negative events (frequency) } \\
\text { Positive events (frequency) } \\
\text { Red (negative events) and green } \\
\text { (positive events) diary } \\
\text { Description of/questions on } \\
\text { events }\end{array}$ & $\begin{array}{l}\text { Fatigue } \\
\text { Chronic social stressors }\end{array}$ & $\begin{array}{l}\text { 1) Negative events increased fatigue } \\
\text { 2) No relation between positive events and fatigue } \\
\text { 3) Positive events decreased fatigue on days with } \\
\text { more negative events } \\
\text { 4) Positive events decreased fatigue when social } \\
\text { stress was high }\end{array}$ \\
\hline $\begin{array}{l}\text { Hoobler et al. } \\
(2010)\end{array}$ & $\begin{array}{l}N=1167 \text { (different } \\
\text { professions) } \\
\text { 2-waves longitudinal } \\
\text { study (12 months apart) }\end{array}$ & $\begin{array}{l}\text { Generalized workplace } \\
\text { harassment (GWH, frequency) } \\
\text { Positive job experience (PJE, } \\
\text { frequency) } \\
\text { GWH list (considering the last } \\
12 \text { months) } \\
\text { PJE list (considering the last } 12 \\
\text { months) }\end{array}$ & $\begin{array}{l}\text { Job stress } \\
\text { Mental health } \\
\text { Physical health }\end{array}$ & $\begin{array}{l}\text { 1) GWH positively predicted job stress at } \mathrm{T} 1 \text { and } \mathrm{T} 2 \\
\text { 2) PJE negatively predicted job stress at } \mathrm{T} 1 \text { and } \mathrm{T} 2 \\
\text { 3) GWH negatively predicted mental health at } \mathrm{T} 1 / \mathrm{T} 2 \\
\text { 4) PJE positively predicted mental health at } \mathrm{T} 1 / \mathrm{T} 2 \\
\text { 5) GWH negatively predicted physical health at } \\
\mathrm{T} 1 / \mathrm{T} 2 \\
\text { 6) PJE positively predicted physical health at } \mathrm{T} 1 / \mathrm{T} 2\end{array}$ \\
\hline
\end{tabular}


Table 1 (continued)

Overview of Studies on Work Events and Well-being at Work

\begin{tabular}{|c|c|c|c|c|}
\hline Authors & $\begin{array}{l}\text { Sample, design, and } \\
\text { analyses }\end{array}$ & Measure of work events & $\begin{array}{l}\text { Measure of } \\
\text { well-being }\end{array}$ & Main findings \\
\hline $\begin{array}{l}\text { Ilies, Keeney, et } \\
\text { al. (2011) }\end{array}$ & $\begin{array}{l}N=52 \text { (non-profit } \\
\text { organization) } \\
\text { ESM 2x per day (3 } \\
\text { weeks) }\end{array}$ & $\begin{array}{l}\text { Positive events (frequency) } \\
\text { Most positive event (intensity) } \\
\text { List of } 36 \text { positive events } \\
\text { description/rating of the most } \\
\text { positive event }\end{array}$ & $\begin{array}{l}\text { Positive affect } \\
\text { Negative affect } \\
\text { Job satisfaction }\end{array}$ & $\begin{array}{l}\text { 1) Intensity of the most positive event increased } \\
\text { positive affect } \\
\text { 2) Frequency of positive events increased positive } \\
\text { affect } \\
\text { 3) No relation between the intensity of the most } \\
\text { positive event and job satisfaction } \\
\text { 4) Frequency of positive events increased job } \\
\text { satisfaction (mediated by positive affect) }\end{array}$ \\
\hline $\begin{array}{l}\text { Ilies, Johnson, et } \\
\text { al. (2011) }\end{array}$ & $\begin{array}{l}N=49 \text { (university } \\
\text { employees) } \\
\text { ESM 3x per day ( } 2 \\
\text { weeks) } \\
\text { HLM }\end{array}$ & $\begin{array}{l}\text { Interpersonal conflict } \\
\text { Social support } \\
\text { List of conflict and support } \\
\text { situations }\end{array}$ & Negative affect & $\begin{array}{l}\text { 1) Interpersonal conflict increased negative affect } \\
\text { 2) Social support decreased the effect of interpersonal } \\
\text { conflict on negative affect }\end{array}$ \\
\hline Ilies et al. (2013) & $\begin{array}{l}N=131 \text { (university } \\
\text { employees) } \\
\text { Retrospective design } \\
\text { (over } 2 \text { weeks) } \\
\text { HLM }\end{array}$ & $\begin{array}{l}\text { Positive events (frequency) } \\
\text { Most positive event (intensity) } \\
\text { List of positive events } \\
\text { Description of the most } \\
\text { important positive event that } \\
\text { week/pleasantness rating }\end{array}$ & $\begin{array}{l}\text { Positive affect } \\
\text { Life satisfaction }\end{array}$ & $\begin{array}{l}\text { 1) Intensity of the most positive event increased } \\
\text { positive affect } \\
\text { 2) Frequency of positive events increased positive } \\
\text { affect } \\
\text { 3) Intensity of the most positive event increased life } \\
\text { satisfaction } \\
\text { 4) No relation between the frequency of positive } \\
\text { events and life satisfaction }\end{array}$ \\
\hline $\begin{array}{l}\text { Koopmann et al. } \\
\text { (2016) }\end{array}$ & $\begin{array}{l}N=75 \text { (different } \\
\text { professions) } \\
\text { ESM 3x per day }(10 \\
\text { days) } \\
\text { HLM }\end{array}$ & $\begin{array}{l}\text { Positive work events } \\
\text { (frequency) } \\
\text { List of } 4 \text { positive and } \\
5 \text { negative events }\end{array}$ & $\begin{array}{l}\text { Mood } \\
\text { Psychosomatic complaints }\end{array}$ & $\begin{array}{l}\text { 1) Positive events increased positive mood (mediated } \\
\text { by promotion focus) } \\
\text { 2) Positive events decreased psychosomatic } \\
\text { complaints (mediated by promotions focus) }\end{array}$ \\
\hline
\end{tabular}


Table 1 (continued)

Overview of Studies on Work Events and Well-being at Work

\begin{tabular}{|c|c|c|c|c|}
\hline Authors & $\begin{array}{l}\text { Sample, design, and } \\
\text { analyses }\end{array}$ & Measure of work events & $\begin{array}{l}\text { Measure of } \\
\text { well-being }\end{array}$ & Main findings \\
\hline $\begin{array}{l}\text { Kuba and Scheibe } \\
\text { (2017) }\end{array}$ & $\begin{array}{l}N=95 \text { (health care } \\
\text { professionals) } \\
\text { ESM 1x per day (10 } \\
\text { days) } \\
\text { HLM }\end{array}$ & $\begin{array}{l}\text { Negative events (frequency) } \\
\text { Open questions on stressful or } \\
\text { pleasant events (up to } 6 \text { events } \\
\text { per day) }\end{array}$ & $\begin{array}{l}\text { Negative affect (end of the } \\
\text { day) } \\
\text { Fatigue (end of the day) } \\
\text { Work engagement }\end{array}$ & $\begin{array}{l}\text { 1) Negative events increased negative affect } \\
\text { 2) Negative events increased fatigue } \\
\text { 3) Negative events decreased work engagement }\end{array}$ \\
\hline $\begin{array}{l}\text { Matta et al. } \\
(2014)\end{array}$ & $\begin{array}{l}N=50 \text { (software } \\
\text { programmers) } \\
\text { Diary 1x per day (10 } \\
\text { working days) } \\
\text { Multilevel path analysis }\end{array}$ & $\begin{array}{l}\text { Work event (occurrence) } \\
\text { Open questions on } 1 \text { event per } \\
\text { day (Positive coded as }+1 \text {, } \\
\text { negative events coded as }-1 \text { ) }\end{array}$ & Negative affect & $\begin{array}{l}\text { 1) Positive work events decrease negative affect after } \\
\text { work } \\
\text { 2) Negative work events increase negative affect after } \\
\text { work }\end{array}$ \\
\hline $\begin{array}{l}\text { Meier et al. } \\
(2014)\end{array}$ & $\begin{array}{l}N=69 \text { (different } \\
\text { professions) } \\
\text { Diary 2x per day }(2 \\
\text { weeks) } \\
\text { HLM }\end{array}$ & $\begin{array}{l}\text { Conflict at work (intensity) } \\
\text { Single item question }\end{array}$ & $\begin{array}{l}\text { State job satisfaction } \\
\text { State depression } \\
\text { State somatic complaints }\end{array}$ & $\begin{array}{l}\text { 1) Conflict decreased state job satisfaction (when } \\
\text { chronic depression symptoms were high) } \\
\text { 2) Conflict increased state depression (when chronic } \\
\text { depression symptoms were high) } \\
\text { 3) Conflict increased state somatic complaints (when } \\
\text { chronic depression symptoms were high) }\end{array}$ \\
\hline $\begin{array}{l}\text { Mignonac and } \\
\text { Herrbach (2004) }\end{array}$ & $\begin{array}{l}N=203 \text { (managers) } \\
\text { Cross-sectional study } \\
\text { Linear regression }\end{array}$ & $\begin{array}{l}\text { Positive events } \\
\text { Negative events } \\
\text { (weighted frequency) } \\
\text { List of } 19 \text { possible events in the } \\
\text { past } 2 \text { months } \\
\text { Rating scale from } 1 \text { (very } \\
\text { negative impact) over } 3 \text { (no } \\
\text { impact) to } 5 \text { (very positive } \\
\text { impact) }\end{array}$ & $\begin{array}{l}\text { Frequency of emotions in } \\
\text { the past week: } \\
\text { Pleasure, comfort, tiredness, } \\
\text { anger, anxiety } \\
\text { Job satisfaction }\end{array}$ & $\begin{array}{l}\text { 1) Negative events increased tiredness, anger, and } \\
\text { anxiety } \\
\text { 2) Negative events decreased pleasure and comfort } \\
\text { 3) Negative events decreased work engagement } \\
\text { 4) Positive events increased pleasure and comfort } \\
\text { 5) Positive events decreased tiredness } \\
\text { 6) Positive events increased work engagement }\end{array}$ \\
\hline
\end{tabular}


Table 1 (continued)

Overview of Studies on Work Events and Well-being at Work

\begin{tabular}{|c|c|c|c|c|}
\hline Authors & $\begin{array}{l}\text { Sample, design, and } \\
\text { analyses }\end{array}$ & Measure of work events & $\begin{array}{l}\text { Measure of } \\
\text { well-being }\end{array}$ & Main findings \\
\hline $\begin{array}{l}\text { Miner et al. } \\
(2005)\end{array}$ & $\begin{array}{l}N=41 \text { (different } \\
\text { professions) } \\
\text { ESM 2x per day (2-3 } \\
\text { workweeks) } \\
\text { HLM }\end{array}$ & $\begin{array}{l}\text { Positive events (work events } \\
\text { supervisor events, coworker } \\
\text { events) } \\
\text { Negative events (work events } \\
\text { supervisor events, coworker } \\
\text { events) (occurrence) }\end{array}$ & Hedonic tone & $\begin{array}{l}\text { 1) All three groups of negative events decreased } \\
\text { hedonic tone } \\
\text { 2) Positive work and coworker events increased } \\
\text { hedonic tone } \\
\text { 3) There was no relation between positive supervisor } \\
\text { events and hedonic tone } \\
\text { 4) Negative events have a stronger effect on hedonic } \\
\text { tone than positive events }\end{array}$ \\
\hline $\begin{array}{l}\text { Moore et al. } \\
\text { (2004) }\end{array}$ & $\begin{array}{l}N=1,244 \text { (manufactory } \\
\text { workers) } \\
\text { 2-wave study ( } 2 \text { years } \\
\text { apart) } \\
\text { MANCOVA }\end{array}$ & Layoff event (occurrence) & $\begin{array}{l}\text { Depression } \\
\text { Physiological health } \\
\text { complaints }\end{array}$ & $\begin{array}{l}\text { 1) Layoff events increased depression } \\
\text { 2) Layoff events increased physiological health } \\
\text { complaints }\end{array}$ \\
\hline $\begin{array}{l}\text { Ohly and Schmitt } \\
\text { (2013) }\end{array}$ & $\begin{array}{l}N=218 \text { (full-time } \\
\text { employees) } \\
\text { Diary } \\
2 \mathrm{x} \text { per day } \\
(\mathrm{N}=155 \text { for } 2 \text { weeks, } \\
\mathrm{N}=63 \text { for } 4 \text { days) } \\
\text { Concept mapping, HLM }\end{array}$ & $\begin{array}{l}\text { Positive events (occurrence, } \\
\text { description) } \\
\text { Negative events (occurrence, } \\
\text { description) }\end{array}$ & $\begin{array}{l}\text { Enthusiasm, at rest, anger, } \\
\text { worry, exhaustion }\end{array}$ & $\begin{array}{l}\text { 1) } 4 \text { clusters of positive events (PE) } \\
\text { 2) } 7 \text { clusters of negative events (NE) } \\
\text { 3) } 4 \mathrm{PE} \text { clusters correlate with enthusiasm } \\
\text { 4) } 3 \mathrm{PE} \text { clusters correlate with at rest } \\
\text { 5) } 6 \mathrm{NE} \text { clusters correlate with anger } \\
\text { 6) } 3 \mathrm{NE} \text { clusters correlate with worry } \\
\text { 7) } 3 \mathrm{NE} \text { clusters correlate with exhaustion } \\
\text { 8) event clusters predict additional variance beyond } \\
\text { occurrence of PE/NE alone in at rest, anger, worry }\end{array}$ \\
\hline
\end{tabular}


Table 1 (continued)

Overview of Studies on Work Events and Well-being at Work

\begin{tabular}{|c|c|c|c|c|}
\hline Authors & $\begin{array}{l}\text { Sample, design, and } \\
\text { analyses }\end{array}$ & Measure of work events & $\begin{array}{l}\text { Measure of } \\
\text { well-being }\end{array}$ & Main findings \\
\hline $\begin{array}{l}\text { Parker et al. } \\
(2020)\end{array}$ & $\begin{array}{l}N=72 \text { (software } \\
\text { programmers) } \\
\text { Diary } 3 x \text { per day ( } 5 \\
\text { working days) } \\
\text { Multilevel mediation } \\
\text { path model }\end{array}$ & $\begin{array}{l}\text { Goal frustrating event } \\
\text { (occurrence) } \\
\text { Goal attainment event } \\
\text { (occurrence) }\end{array}$ & $\begin{array}{l}\text { Evening relaxation } \\
\text { Next-morning energy }\end{array}$ & $\begin{array}{l}\text { 1) Goal frustration event decrease evening relaxation } \\
\text { between and within persons } \\
\text { 2) Goal attainment event increase evening relaxation } \\
\text { between but not within persons } \\
\text { 3) Goal-frustration events decrease next morning } \\
\text { energy via evening relaxation within but not between } \\
\text { persons } \\
\text { 4) No relation between goal-attainment events on } \\
\text { next morning energy }\end{array}$ \\
\hline $\begin{array}{l}\text { Paterson and } \\
\text { Cary, (2002) }\end{array}$ & $\begin{array}{l}N=71 \text { (employees in the } \\
\text { public sector) } \\
\text { Retrospective survey } \\
\text { Path analysis }\end{array}$ & $\begin{array}{l}\text { Downsizing event (intensity of } \\
\text { affective appraisal) }\end{array}$ & Change anxiety & $\begin{array}{l}\text { 1) Negative affective appraisal increased change } \\
\text { anxiety compared to positive affective appraisal }\end{array}$ \\
\hline $\begin{array}{l}\text { Potter et al. } \\
(2002)\end{array}$ & $\begin{array}{l}N=109 \text { (working female } \\
\text { arthritis patients) } \\
\text { Longitudinal study, } \\
\text { weekly phone interviews } \\
\text { (12 weeks) } \\
\text { HLM }\end{array}$ & $\begin{array}{l}\text { List of } 9 \text { work-related } \\
\text { interpersonal stressor events }\end{array}$ & $\begin{array}{l}\text { Negative affect } \\
\text { Disease-specific physical } \\
\text { well-being }\end{array}$ & $\begin{array}{l}\text { 1) Interpersonal stressor events increased negative } \\
\text { affect } \\
\text { 2) Interpersonal stressor events decreased disease- } \\
\text { specific physical well-being }\end{array}$ \\
\hline
\end{tabular}


Table 1 (continued)

Overview of Studies on Work Events and Well-being at Work

\begin{tabular}{|c|c|c|c|c|}
\hline Authors & $\begin{array}{l}\text { Sample, design, and } \\
\text { analyses }\end{array}$ & Measure of work events & $\begin{array}{l}\text { Measure of } \\
\text { well-being }\end{array}$ & Main findings \\
\hline $\begin{array}{l}\text { Rothbard and } \\
\text { Wilk (2011) }\end{array}$ & $\begin{array}{l}N=28 \text { customer service } \\
\text { representatives } \\
\text { ESM } 3 x \text { per day } \\
\text { ( } 3 \text { weeks) } \\
\text { HLM }\end{array}$ & $\begin{array}{l}\text { Perceived customer positive } \\
\text { affective display during a call } \\
\text { Perceived customer negative } \\
\text { affective display during a call }\end{array}$ & $\begin{array}{l}\text { Positive affect } \\
\text { Negative affect }\end{array}$ & $\begin{array}{l}\text { 1) Start-of-workday positive mood was positively } \\
\text { related to perceived customer positive affective } \\
\text { display } \\
\text { 2) Start-of-workday negative mood was positively } \\
\text { related to perceived customer negative affective } \\
\text { display } \\
\text { 3) Perceived customer positive affective display was } \\
\text { positively related to employee positive affect } \\
\text { subsequent to the call } \\
\text { 4) Perceived customer negative affective display was } \\
\text { negatively related to employee negative affect } \\
\text { subsequent to the call }\end{array}$ \\
\hline
\end{tabular}

Rueff Lopes et al. $\quad N=80$ (call center (2017) service) Diary $1 \mathrm{x}$ per day $(10$ workdays)

Positive customer-related events (occurrence, description)

Negative customer-related

Positive affect

Negative affect

events (occurrence, description)

ANN

Todorova, Bear, and Weingart

(2014)
Mild/intense task conflict

Task conflict expression scale
Cardiovascular efficiency

Positive active emotions

Job satisfaction
1) Negative affect aroused by customer-related events increased cardiovascular efficiency

2) Positive affect aroused by customer-related events increased cardiovascular efficiency 2-wave longitudinal study (2 months apart)
HLM
1) Mild task conflict increased positive active emotions (mediated by information acquisition) 2) Intense task conflict decreased positive active emotions (mediated by information acquisition) 3) Mild task conflict increased job satisfaction (mediated by information acquisition and positive active emotions)

4) Intense task conflict decreased job satisfaction (mediated by information acquisition and positive active emotions) 
Table 1 (continued)

Overview of Studies on Work Events and Well-being at Work

\begin{tabular}{|c|c|c|c|c|}
\hline Authors & $\begin{array}{l}\text { Sample, design, and } \\
\text { analyses }\end{array}$ & Measure of work events & $\begin{array}{l}\text { Measure of } \\
\text { well-being }\end{array}$ & Main findings \\
\hline $\begin{array}{l}\text { Volmer et al. } \\
\text { (2012) }\end{array}$ & $\begin{array}{l}N=138 \text { (civil service } \\
\text { agents) } \\
\text { Diary design } 2 x \text { per day } \\
\text { ( } 5 \text { days) } \\
\text { HLM }\end{array}$ & $\begin{array}{l}\text { Social customer conflict (SCC, } \\
\text { weighted frequency) } \\
\text { List of } 16 \text { items on social } \\
\text { customer conflict (rating scale } \\
1-5 \text { ) }\end{array}$ & $\begin{array}{l}\text { Work detachment } \\
\text { Positive affect } \\
\text { Negative affect }\end{array}$ & $\begin{array}{l}\text { 1) SCC increased negative affect } \\
\text { 2) No relation between SCC and positive affect } \\
\text { 3) SCC decreased work detachment (mediated by } \\
\text { negative affect) }\end{array}$ \\
\hline $\begin{array}{l}\text { Wang et al. } \\
(2019)\end{array}$ & $\begin{array}{l}N=200 \text { (university } \\
\text { employees) } \\
\text { ESM 5x per day ( } 8 \\
\text { successive workdays) } \\
\text { MSEM }\end{array}$ & $\begin{array}{l}\text { Achievement events (frequency) } \\
\text { Recognition events (frequency) } \\
\text { List of achievement and } \\
\text { recognition events (before noon) }\end{array}$ & $\begin{array}{l}\text { Work engagement } \\
\text { Autonomy-need satisfaction } \\
\text { Competence-need } \\
\text { satisfaction } \\
\text { Relatedness-need } \\
\text { satisfaction }\end{array}$ & $\begin{array}{l}\text { 1) Achievement events increased work engagement } \\
\text { 2) Recognition events increased work engagement } \\
\text { 3) Achievement events increased autonomy-/ } \\
\text { competence-/ relatedness-need satisfaction } \\
\text { 4) Recognition events increased competence-/ } \\
\text { relatedness-need satisfaction }\end{array}$ \\
\hline Zohar (1999) & $\begin{array}{l}N=41 \text { (military jump } \\
\text { masters) } \\
\text { Diary 3x per day ( } 5 \\
\text { working days) } \\
\text { Pooled-time series } \\
\text { analysis }\end{array}$ & Unexpected hassles (severity) & $\begin{array}{l}\text { Negative mood } \\
\text { Fatigue }\end{array}$ & $\begin{array}{l}\text { 1) Daily unexpected hassle severity increased } \\
\text { negative mood } \\
\text { 2) Daily unexpected hassle severity increased fatigue } \\
\text { 3) The relationship between hassle severity and } \\
\text { negative mood was stronger when assignment } \\
\text { complexity was high }\end{array}$ \\
\hline \multirow[t]{2}{*}{$\begin{array}{l}\text { Zohar et al. } \\
(2003)\end{array}$} & $\begin{array}{l}N=78 \text { (health care } \\
\text { professionals) } \\
\text { ESM 3x per day ( } 3 \text { days) }\end{array}$ & $\begin{array}{l}\text { Goal-disruptive events } \\
\text { (frequency) } \\
\text { Goal-enhancing events } \\
\text { (frequency) }\end{array}$ & $\begin{array}{l}\text { Positive affect } \\
\text { Negative affect } \\
\text { Fatigue }\end{array}$ & $\begin{array}{l}\text { 1) Goal-disruptive events increased negative affect } \\
\text { 2) Goal-enhancing events increased positive affect } \\
\text { 3) Goal-disruptive events increased fatigue } \\
\text { 4) No relation between goal-enhancing events and } \\
\text { fatigue }\end{array}$ \\
\hline & HLM & $\begin{array}{l}3 \text { questions on goal-disruptive } \\
\text { events, } 3 \text { questions on goal- } \\
\text { enhancing events }\end{array}$ & & \\
\hline
\end{tabular}

Note. The studies in Table 1 are an illustrative collection of articles on the relation of affective work events on well-being. We include articles published since the release of the affective event framework in 1996. Specifically, we include articles from Academy of Management Journal, Journal of Applied Psychology,, Journal of Occupational Health Pyychology, Journal of Occupational and Organizational Psychology, Journal of Organizational Behavior, Work and Stress, Journal of Business and Psychology, European Journal of Work and Organizational Psychology, Organizational
Behavior and Human Decision Processes, Applied Psychology-An International Review, and Motivation and Emotion. We used the keywords "work events well-being", "affective events well-being", "“work events affect", "affective work events", "positive work events", "negative work events", "work event conflict", "well-being event conflict", and "conflict at work well-being". We restricted the results to quantitative research on self-contained events with a clear beginning and end. We further excluded studies describing broad behavior, general stress, and general conflict as events. 
Table 2

Study 1: Fit Indices for All Confirmatory Factor Analysis Models for Work Events Nested in Persons and for Workdays Nested in Persons, and Fit Indices for the Measurement Model for Workdays Nested in Persons including Emotional Exhaustion, Positive and Negative Affect

\begin{tabular}{|c|c|c|c|c|c|c|c|c|}
\hline Structure & $k$ & $\chi^{2}$ & $d f$ & $p$ & $C F I$ & RMSEA & $\begin{array}{c}\text { SRMR } \\
\text { between }\end{array}$ & $\begin{array}{l}\text { SRMR } \\
\text { within }\end{array}$ \\
\hline \multicolumn{9}{|l|}{ CFA } \\
\hline \multicolumn{9}{|l|}{ Events nested in persons } \\
\hline Model 1: 2-factor model & 3,693 & $25,664.083$ & 698 & $<.001$ & .522 & .098 & .216 & .141 \\
\hline Model 2: 4-factor model & 3,693 & $11,361.246$ & 688 & $<.001$ & .796 & .065 & .159 & .096 \\
\hline Model 3: 7-factor model & 3,693 & $6,010.349$ & 658 & $<.001$ & .898 & .047 & .142 & .078 \\
\hline Model 4: 7-factor model, reduced & 3,693 & $1,796.766$ & 336 & $<.001$ & .962 & .034 & .094 & .048 \\
\hline \multicolumn{9}{|l|}{ Days nested in persons } \\
\hline Model 1: 2-factor model & 1,172 & $9,207.666$ & 698 & $<.001$ & .531 & .102 & .243 & .143 \\
\hline Model 2: 4-factor model & 1,172 & $4,532.054$ & 688 & $<.001$ & .788 & .069 & .169 & .098 \\
\hline Model 3: 7-factor model & 1,172 & $2,636.527$ & 658 & $<.001$ & .891 & .051 & .179 & .081 \\
\hline Model 4: 7-factor model, reduced & 1,172 & 889.914 & 336 & $<.001$ & .958 & .038 & .096 & .046 \\
\hline \multicolumn{9}{|l|}{ Measurement model } \\
\hline \multicolumn{9}{|l|}{ Days nested in persons } \\
\hline Model 5: CAPTION and EE/PANAS & 1,172 & $4,543.663$ & 1,830 & $<.001$ & .903 & .036 & .092 & .042 \\
\hline
\end{tabular}

Note. $k=$ events/days nested in $N=242$ persons. CFI = confirmatory fit index; RMSEA = root mean square error of approximation; SRMR = standardized root mean square residual; $\mathrm{CFA}=$ confirmatory factor analysis; $\mathrm{EE}=$ emotional exhaustion; PANAS $=$ positive affect negative affect scale $* p<.05 ; * *<.01$. 
Table 3

Study 1: Latent Variable Correlations from the Measurement Model (Model 5) for all CAPTION Dimensions, Emotional Exhaustion (After Work), Positive Affect, and Negative Affect (Morning and After Work) and Latent Variable Reliabilities at the Between-and at the Within-Person Level

\begin{tabular}{|c|c|c|c|c|c|c|c|c|c|c|c|c|}
\hline Variable & 1. & 2. & 3. & 4. & 5. & 6. & 7. & 8. & 9. & 10. & 11. & 12. \\
\hline $\begin{array}{l}\text { 1. Positive affect } \\
\text { (morning) }\end{array}$ & - & $-.56 * *$ & .02 & -.03 & $.19 * *$ & .03 & $.08 *$ & $.09 *$ & -.03 & $-.13 * *$ & $22 * *$ & -.05 \\
\hline $\begin{array}{l}\text { 2. Negative affect } \\
\text { (morning) }\end{array}$ & .06 & - & .03 & $.15 * *$ & $-.09 *$ & -.06 & -.08 & -.01 & $.13 * *$ & $.18 * *$ & $-.10 *$ & $.17^{* *}$ \\
\hline 3. Complexity & $.24 * *$ & $.30 * *$ & - & $-.18 * *$ & .06 & $.28 * *$ & $.62 * *$ & $-.12 * *$ & $-.10 *$ & -.03 & .08 & -.08 \\
\hline 4. Adversity & .01 & $.48 * *$ & -.00 & - & $-.54 * *$ & $-.32 * *$ & $-.54 * *$ & $-.17 * *$ & $.50 * *$ & $.49 * *$ & $-.37 * *$ & $.45 * *$ \\
\hline 5. Positive valence & $.26 * *$ & $.37 * *$ & $.52 * *$ & .08 & - & $.09 *$ & $.36 * *$ & $.40 * *$ & $-.28 * *$ & $-.26 * *$ & $.32 * *$ & $-.18 * *$ \\
\hline 6. Typicality & $.21 *$ & $.19^{*}$ & $.34 * *$ & -.04 & .00 & - & $.39 * *$ & .02 & $-.21 * *$ & $-.14 * *$ & .07 & $-.12 * *$ \\
\hline 7. Importance & $.25 * *$ & .13 & $.74 * *$ & -.12 & $.48 * *$ & $.46^{* *}$ & - & -.00 & $-.34 * *$ & $-.23 * *$ & $.26^{* *}$ &.$-25 * *$ \\
\hline 8. Humor & $.21 *$ & $.35 * *$ & $.32 * *$ & $.34 * *$ & $.30 * *$ & .18 & $.26 * *$ & - & -.00 & $-.14 * *$ & $.23 * *$ & -.04 \\
\hline 9. Negative valence & .16 & $.63 * *$ & .15 & $.58 * *$ & .15 & .13 & .15 & $.73 * *$ & - & $.35 * *$ & $-.23 * *$ & $.37 * *$ \\
\hline $\begin{array}{l}\text { 10. Emotional } \\
\text { exhaustion }\end{array}$ & -.08 & $.47 * *$ & .12 & $.59 * *$ & .15 & .13 & .13 & $.24 * *$ & $.43 * *$ & - & $-.62 * *$ & $.70 * *$ \\
\hline $\begin{array}{l}\text { 11. Positive affect } \\
\text { (after work) }\end{array}$ & $.85 * *$ & -.03 & $.31 * *$ & .02 & $.34 * *$ & $.24 * *$ & $.33 * *$ & $.32 * *$ & .09 & -.10 & - & $-.67 * *$ \\
\hline $\begin{array}{l}\text { 12. Negative affect } \\
\text { (after work) }\end{array}$ & .05 & $.91 * *$ & $.29 * *$ & $.63 * *$ & $.36^{* *}$ & .07 & $.23 *$ & $.57 * *$ & $.91 * *$ & $.68 * *$ & .08 & - \\
\hline Reliability between & .93 & .84 & .88 & .91 & .90 & .97 & .94 & .85 & .87 & .94 & .92 & .85 \\
\hline Reliability within & .83 & .63 & .73 & .89 & .87 & .89 & .87 & .64 & .73 & .87 & .82 & .74 \\
\hline
\end{tabular}

Note. Correlations below the diagonal are between-person correlations $(N=242)$. Correlations above the diagonal are within-person correlations $(k=1,172)$. Reliability is calculated using confirmatory factor analysis-based Cronbach's $\alpha$ estimation. $* p<.05 ; * * p<.01$. 
Table 4

Study 1: Fit Indices for All Competing Structural Models and Results for $\chi^{2}$ Difference Tests for Emotional Exhaustion, Positive and Negative Affect

\begin{tabular}{|c|c|c|c|c|c|c|c|}
\hline Structure & $\chi^{2}$ & $d f$ & $p$ & CFI & RMSEA & $\begin{array}{c}\text { SRMR } \\
\text { between }\end{array}$ & $\begin{array}{l}\text { SRMR } \\
\text { within }\end{array}$ \\
\hline \multicolumn{8}{|l|}{ Structural model } \\
\hline $\begin{array}{l}\text { Model 6a: constrained } \\
\qquad \mathrm{P}+\mathrm{N} \text { predict EE/PANAS }\end{array}$ & $4,709.503$ & 1,860 & $<.001$ & .898 & .036 & .101 & .050 \\
\hline $\begin{array}{l}\text { Model 6b: constrained } \\
\qquad \begin{array}{l}\mathrm{P}+\mathrm{N}+\mathrm{A}+\mathrm{O} \text { predict } \\
\text { EE/PANAS }\end{array}\end{array}$ & $4,571.498$ & 1,848 & $<.001$ & .903 & .035 & .094 & .043 \\
\hline vs. Model 6a & $132.219 * * *$ & 12 & & -.005 & .001 & .007 & .007 \\
\hline $\begin{array}{l}\text { Model 6c: constrained } \\
\qquad \begin{array}{l}\mathrm{P}+\mathrm{N}+\mathrm{C}+\mathrm{I}+\mathrm{T} \text { predict } \\
\text { EE/PANAS }\end{array}\end{array}$ & $4,680.733$ & 1,842 & $<.001$ & .899 & .036 & .102 & .048 \\
\hline vs. Model 6a & $32.635^{*}$ & 18 & & -.001 & .000 & .001 & .002 \\
\hline $\begin{array}{l}\text { Model 6d: unconstrained } \\
\text { full CAPTION predicts } \\
\text { EE/PANAS }\end{array}$ & $4,543.663$ & 1,830 & $<.001$ & .903 & .036 & .092 & .042 \\
\hline vs. Model 6a & $161.122 * * *$ & 30 & & -.005 & .000 & .009 & .008 \\
\hline vs. Model 6b & 28.627 & 18 & & .000 & -.001 & .002 & .001 \\
\hline vs. Model 6c & $128.622 * * *$ & 12 & & -.004 & .000 & .010 & .006 \\
\hline
\end{tabular}

Note. $k=1,172$ days nested in $N=242$ persons. $\mathrm{CFI}=$ confirmatory fit index; RMSEA $=$ root mean square error of approximation; SRMR $=$ standardized root mean square residual; $\mathrm{CFA}=$ confirmatory factor analysis; $\mathrm{EE}=$ emotional exhaustion; $\mathrm{PANAS}=$ positive affect negative affect scale; $\mathrm{P}=$ positive valence; $\mathrm{N}=$ negative valence; $\mathrm{A}=$ adversity; $\mathrm{O}=$ humor; $\mathrm{C}=$ complexity; $\mathrm{I}=$ importance; $\mathrm{T}=$ typicality. $* p<.05 ; * *<.01 ; * * * p<.001$ 
Table 5

Study 1: Structural Equation Estimates and Test Statistics for the Structural Model (Model 6d) Predicting Emotional Exhaustion After Work,

Positive Affect After Work, and Negative Affect After Work with All Seven CAPTION Dimensions Controlled for Positive Affect in the Morning and Negative Affect in the Morning at the Between- and at the Within-Person Level

\begin{tabular}{|c|c|c|c|c|c|c|}
\hline \multirow[b]{2}{*}{ Variable } & \multicolumn{2}{|c|}{ Emotional exhaustion } & \multicolumn{2}{|c|}{ Positive affect } & \multicolumn{2}{|c|}{ Negative affect } \\
\hline & Estimate & $z$ & Estimate & $z$ & Estimate & $z$ \\
\hline \multicolumn{7}{|l|}{ Between person } \\
\hline Positive affect (morning) & -.15 & -1.85 & .79 & $9.28 * *$ & -.07 & -0.89 \\
\hline Negative affect (morning) & .23 & 1.11 & -.09 & -0.49 & .54 & $2.44^{*}$ \\
\hline Complexity & -.14 & -0.81 & -.04 & -0.25 & -.01 & -0.06 \\
\hline Adversity & .54 & $4.05 * *$ & .15 & 1.32 & .08 & 0.58 \\
\hline Positive valence & .02 & 0.14 & .09 & 0.73 & .02 & 0.17 \\
\hline Typicality & .08 & 0.75 & .05 & 0.53 & -.15 & -1.33 \\
\hline Importance & .26 & 1.35 & .08 & 0.47 & .18 & 0.91 \\
\hline Humor & -.01 & -0.04 & .36 & 1.63 & -.08 & -0.34 \\
\hline Negative valence & -.03 & -0.10 & -.35 & -1.20 & .58 & 1.75 \\
\hline \multicolumn{7}{|l|}{ Within person } \\
\hline Positive affect (morning) & -.10 & $-2.11 *$ & .24 & $4.43 * *$ & .00 & 0.08 \\
\hline Negative affect (morning) & .04 & 0.70 & .09 & 1.56 & .10 & 1.64 \\
\hline Complexity & .03 & 0.46 & -.01 & -0.18 & -.00 & -0.06 \\
\hline Adversity & .46 & $8.28 * *$ & -.27 & $-4.61 * *$ & .40 & $6.51 * *$ \\
\hline Positive valence & .07 & 1.51 & .03 & 0.48 & .11 & $1.98 *$ \\
\hline Typicality & .02 & 0.44 & -.08 & $-2.05^{*}$ & .05 & 1.36 \\
\hline Importance & .04 & 0.57 & .11 & 1.63 & -.03 & -0.37 \\
\hline Humor & -.08 & -1.83 & .15 & $3.10 * *$ & -.02 & -0.30 \\
\hline Negative valence & .15 & $3.41 * *$ & -.07 & -1.50 & .19 & $3.95 * *$ \\
\hline Model 6a: $R^{2}$ between & & .31 & & .80 & & 1.00 \\
\hline Model 6a: $R^{2}$ within & & .21 & & .17 & & .21 \\
\hline Model 6b: $R^{2}$ between & & .44 & & .82 & & 1.00 \\
\hline Model 6b: $R^{2}$ within & & .28 & & .21 & & .24 \\
\hline Model 6c: $R^{2}$ between & & .34 & & .83 & & 1.00 \\
\hline Model 6c: $R^{2}$ within & & .22 & & .19 & & .21 \\
\hline Model 6d: $R^{2}$ between & & .46 & & .82 & & 1.00 \\
\hline Model 6d: $R^{2}$ within & & .28 & & .22 & & .25 \\
\hline
\end{tabular}

Note. $* p<.05 ; * p<.01$ 
Table 6

Study 2: Fit Indices for All Confirmatory Factor Analysis Models for Work Events Nested in Persons and for Workdays Nested in Persons, and Fit Indices for the Measurement Model for Work Events Nested in Persons including Discrete Emotions at Work

\begin{tabular}{|c|c|c|c|c|c|c|c|c|}
\hline Structure & $k$ & $\chi^{2}$ & $d f$ & $p$ & CFI & RMSEA & $\begin{array}{l}\text { SRMR } \\
\text { between }\end{array}$ & $\begin{array}{l}\text { SRMR } \\
\text { within }\end{array}$ \\
\hline \multicolumn{9}{|l|}{ CFA } \\
\hline \multicolumn{9}{|l|}{ Events nested in persons } \\
\hline $\begin{array}{l}\text { Model 7: 7-factor model, reduced } \\
\text { Days nested in persons }\end{array}$ & 1,587 & 642.792 & 336 & $<.001$ & .974 & .024 & .105 & .046 \\
\hline $\begin{array}{l}\text { Model 7: 7-factor model, reduced } \\
\text { Measurement model }\end{array}$ & 1,298 & 515.732 & 336 & $<.001$ & .964 & .020 & .075 & .052 \\
\hline Events nested in persons & & & & & & & & \\
\hline Model 8: CAPTION and emotions & 1,587 & $1,540.102$ & 880 & $<.001$ & .971 & .022 & .094 & .043 \\
\hline
\end{tabular}

Note. $k=$ events/days nested in $N=295$ persons. $\mathrm{CFI}=$ confirmatory fit index; RMSEA = root mean square error of approximation; SRMR = standardized root mean square residual; $\mathrm{CFA}=$ confirmatory factor analysis. $* p<.05 ; * *<.01$. 
Table 7

Study 2: Latent Variable Correlations from the Measurement Model (Model 8) for all CAPTION Dimensions and all Four Emotions at Work, and Latent Variable Reliabilities at the Between-and at the Within-Person Level

\begin{tabular}{|c|c|c|c|c|c|c|c|c|c|c|c|}
\hline Variable & 1. & 2. & 3. & 4. & 5. & 6. & 7. & 8. & 9. & 10. & 11. \\
\hline 1. Complexity & - & $-.19 * *$ & $.08 *$ & $.15 * *$ & $.55 * *$ & $-.17 * *$ & $-.17 * *$ & $.23 * *$ & $.36 * *$ & $-.19 * *$ & $-.10 *$ \\
\hline 2. Adversity & $.42 * *$ & - & $-.56 * *$ & $-.40 * *$ & $-.50 * *$ & $-.36 * *$ & $.64 * *$ & $-.66 * *$ & $-.52 * *$ & $.81 * *$ & $.34 * *$ \\
\hline 3. Positive valence & .11 & .08 & - & $.17 * *$ & $.37 * *$ & $.47 * *$ & $-.43 * *$ & $.62 * *$ & $.49 * *$ & $-.45 * *$ & $-.12 *$ \\
\hline 4. Typicality & $.32 *$ & -.00 & -.03 & - & $.32 * *$ & $.12 * *$ & $-.30 * *$ & $.28 * *$ & $.22 * *$ & $-.27 * *$ & $-.16^{* *}$ \\
\hline 5. Importance & $.62 * *$ & -.01 & $.32 * *$ & $.43^{* *}$ & - & -.03 & $-.43 * *$ & $.48 * *$ & $.54 * *$ & $-.44 * *$ & $-.21 * *$ \\
\hline 6. Humor & .22 & .37 & .45 & -.00 & .01 & - & -.09 & $.39 * *$ & $.24 * *$ & $-.27 * *$ & -.07 \\
\hline 7. Negative valence & .27 & $.70 * *$ & .14 & -.09 & -.12 & $.51 * *$ & - & $-.44 * *$ & $-.38 * *$ & $.63 * *$ & $.28 * *$ \\
\hline 8. Joy & .10 & -.00 & $.45 * *$ & $.28 * *$ & $.44 * *$ & .21 & $-.22 *$ & - & $.76 * *$ & $-.65 * *$ & $-.31 * *$ \\
\hline 9. Pride & .29 & .21 & $.53 * *$ & .19 & $.50 * *$ & .26 & .06 & $.80 * *$ & - & $-.51 * *$ & $-.34 * *$ \\
\hline 10. Anger & $.30 *$ & $.87 * *$ & .06 & -.04 & .00 & .32 & $.73 * *$ & -.12 & .14 & - & $.30 * *$ \\
\hline 11. Guilt & .19 & $.49 * *$ & .14 & .05 & .04 & $.39 *$ & $.54 * *$ & .02 & .06 & $.55 * *$ & - \\
\hline Reliability between & .71 & .89 & .89 & .96 & .95 & .67 & .87 & .96 & .90 & .96 & .92 \\
\hline Reliability within & .72 & .80 & .84 & .88 & .89 & .71 & .72 & .91 & .81 & .91 & .68 \\
\hline
\end{tabular}

Note. Correlations below the diagonal are between-person correlations $(N=295$
calculated using confirmatory factor analysis-based Cronbach's $\alpha$ estimation. $* p<.05 ; * * p<.01$ 
Table 8

Study 2: Fit Indices for All Competing Structural Models and Results for $\chi^{2}$ Difference Tests for Discrete Emotions at Work

\begin{tabular}{|c|c|c|c|c|c|c|c|}
\hline Structure & $\chi^{2}$ & $d f$ & $p$ & $C F I$ & RMSEA & $\begin{array}{c}\text { SRMR } \\
\text { between }\end{array}$ & $\begin{array}{l}S R M R \\
\text { within }\end{array}$ \\
\hline \multicolumn{8}{|l|}{ Structural model } \\
\hline $\begin{array}{l}\text { Model 9a: constrained } \\
\qquad \mathrm{P}+\mathrm{N} \text { predict emotions }\end{array}$ & $1,890.091$ & 920 & $<.001$ & .958 & .026 & .129 & .056 \\
\hline $\begin{array}{l}\text { Model 9b: constrained } \\
\qquad \mathrm{P}+\mathrm{N}+\mathrm{A}+\mathrm{H} \text { predict emotions }\end{array}$ & $1,617.918$ & 904 & $<.001$ & .969 & .022 & .116 & .052 \\
\hline vs. Model 9a & $188.271 * * *$ & 16 & & -.011 & .004 & .013 & .004 \\
\hline $\begin{array}{l}\text { Model 9c: constrained } \\
\qquad \mathrm{P}+\mathrm{N}+\mathrm{C}+\mathrm{I}+\mathrm{T} \text { predict emotions }\end{array}$ & $1,839.168$ & 896 & $<.001$ & .959 & .026 & .116 & .047 \\
\hline vs. Model 9a & $187.534 * * *$ & 24 & & -.001 & .000 & .013 & .009 \\
\hline $\begin{array}{l}\text { Model 9d: unconstrained } \\
\text { full CAPTION predicts emotions }\end{array}$ & $1,540.102$ & 880 & $<.001$ & .971 & .022 & .096 & .043 \\
\hline vs. Model 9a & $340.121 * * *$ & 40 & & -.013 & .004 & .033 & .013 \\
\hline vs. Model 9b & $166.687 * * *$ & 24 & & -.002 & .000 & .020 & .009 \\
\hline vs. Model 9c & $205.829 * * *$ & 16 & & -.012 & .004 & .010 & .004 \\
\hline
\end{tabular}

Note. $k=1,587$ events nested in $N=295$ persons. CFI = confirmatory fit index; RMSEA = root mean square error of approximation; SRMR $=$ standardized root mean square residual; $\mathrm{CFA}=$ confirmatory factor analysis; $\mathrm{P}=$ positive valence; $\mathrm{N}=$ negative valence; $\mathrm{A}=$ adversity; $\mathrm{O}=$ humor; $\mathrm{C}=$ complexity; $\mathrm{I}=$ importance; $\mathrm{T}=$ typicality. $* p<.05 ; * * p<.01$. 
Table 9

Study 2: Structural Equation Estimates and Test Statistics for the Structural Model (Model 9d) Predicting Emotions at Work with All Seven CAPTION Dimensions at the Between- and at the Within-Person Level

\begin{tabular}{|c|c|c|c|c|c|c|c|c|}
\hline \multirow[b]{2}{*}{ Variable } & \multicolumn{2}{|c|}{ Joy } & \multicolumn{2}{|c|}{ Pride } & \multicolumn{2}{|c|}{ Anger } & \multicolumn{2}{|c|}{ Guilt } \\
\hline & Estimate & $z$ & Estimate & $z$ & Estimate & $z$ & Estimate & $z$ \\
\hline \multicolumn{9}{|l|}{ Between person } \\
\hline Complexity & -.51 & -1.37 & -.24 & -0.84 & -.27 & -1.17 & -.24 & -0.70 \\
\hline Adversity & .48 & 1.55 & .41 & 1.59 & .82 & $3.60 * *$ & .29 & 0.96 \\
\hline Positive valence & .20 & 1.02 & .34 & $2.02 *$ & -.08 & -0.67 & -.08 & -0.44 \\
\hline Typicality & .14 & 1.19 & .04 & 0.34 & -.04 & -0.54 & .06 & 0.50 \\
\hline Importance & .55 & 1.56 & .50 & 1.74 & .26 & 1.15 & .24 & 0.68 \\
\hline Humor & .34 & 1.31 & .10 & 0.47 & -.03 & -0.20 & .25 & 0.80 \\
\hline Negative valence & -.56 & $-2.20 *$ & -.22 & -0.99 & .28 & 1.31 & .34 & 1.36 \\
\hline \multicolumn{9}{|l|}{ Within person } \\
\hline Complexity & .09 & $2.52^{*}$ & .18 & $4.29 * *$ & -.04 & -1.12 & -.00 & -0.05 \\
\hline Adversity & -.36 & $-6.95 * *$ & -.19 & $-3.45^{* *}$ & .72 & $12.56^{* *}$ & .30 & $3.64 * *$ \\
\hline Positive valence & .30 & $7.45 * *$ & .21 & $4.63^{* *}$ & .04 & 1.06 & .12 & 1.88 \\
\hline Typicality & .02 & 0.55 & -.03 & -0.88 & .09 & $3.56^{* *}$ & -.01 & -0.22 \\
\hline Importance & .15 & $3.62 * *$ & .27 & $5.73 * *$ & -.02 & -0.44 & -.05 & -0.80 \\
\hline Humor & .15 & $3.78 * *$ & .12 & $2.65 * *$ & -.02 & -0.67 & -.00 & -0.06 \\
\hline Negative valence & .01 & 0.30 & -.01 & -0.20 & .20 & $4.43 * *$ & .11 & 1.29 \\
\hline Model 9a: $R^{2}$ between & & .30 & & .35 & & .66 & & .31 \\
\hline Model 9a: $R^{2}$ within & & .56 & & .37 & & .75 & & .15 \\
\hline Model 9b: $R^{2}$ between & & .62 & & .62 & & .81 & & .36 \\
\hline Model 9b: $R^{2}$ within & & .56 & & .37 & & .68 & & .13 \\
\hline Model 9c: $R^{2}$ between & & .39 & & .45 & & .75 & & .38 \\
\hline Model 9c: $R^{2}$ within & & .55 & & .43 & & .72 & & .14 \\
\hline Model 9d: $R^{2}$ between & & .56 & & .48 & & .84 & & .40 \\
\hline Model 9d: $R^{2}$ within & & .57 & & .44 & & .69 & & .13 \\
\hline
\end{tabular}

Note. ${ }^{*} p<.05 ; * * p<.01$. 
Table 10

Overview of Specific Relations Between CAPTION Dimensions and Well-being Indicators

\begin{tabular}{|c|c|c|c|c|c|c|c|}
\hline Variable & $\begin{array}{c}\text { Positive } \\
\text { affect }\end{array}$ & Joy & Pride & $\begin{array}{l}\text { Emotional } \\
\text { exhaustion }\end{array}$ & $\begin{array}{c}\text { Negative } \\
\text { affect }\end{array}$ & Anger & Guilt \\
\hline \multicolumn{8}{|l|}{ Between-person } \\
\hline \multicolumn{8}{|l|}{ Complexity } \\
\hline$\underline{\text { Adversity }}$ & & & & $\mathrm{x}$ & & $\mathrm{x}$ & \\
\hline Positive valence & & & $\mathrm{x}$ & & & & \\
\hline \multicolumn{8}{|l|}{ Typicality } \\
\hline \multicolumn{8}{|l|}{ Importance } \\
\hline \multicolumn{8}{|l|}{ Humor } \\
\hline Negative valence & & $\mathrm{x}$ & & & & & \\
\hline \multicolumn{8}{|l|}{ Within-person } \\
\hline Complexity & & $\mathrm{x}$ & $\mathrm{x}$ & & & & \\
\hline$\underline{\text { A}}$ dversity & $\mathrm{x}$ & $\mathrm{x}$ & $\mathrm{x}$ & $\mathrm{x}$ & $\mathrm{x}$ & $\mathrm{x}$ & $\mathrm{x}$ \\
\hline Positive valence & & $\mathrm{x}$ & $\mathrm{x}$ & & $\mathrm{x}$ & & \\
\hline Typicality & $\mathrm{x}$ & & & & & $\mathrm{x}$ & \\
\hline Importance & & $\mathrm{x}$ & $\mathrm{x}$ & & & & \\
\hline Humor & $\mathrm{x}$ & $\mathrm{x}$ & $\mathrm{x}$ & & & & \\
\hline Negative valence & & & & $\mathrm{x}$ & $\mathrm{x}$ & $\mathrm{x}$ & \\
\hline
\end{tabular}

Note. $\mathrm{x}=$ significant link. 


\begin{tabular}{|c|c|c|}
\hline CAPTION & \multirow[t]{3}{*}{ between } & Well-being \\
\hline$\underline{N}$ egative valence & & Study 1 -after work: \\
\hline Positive valence & & Emotional exhaustion \\
\hline$\underline{\text { Adversity }}$ & $\mathrm{H} 2$ & Negative affect \\
\hline humor & \multirow{4}{*}{$\begin{array}{l}\mathrm{H} 2 \\
\mathrm{H} 4\end{array}$} & \multirow{4}{*}{$\begin{array}{l}\text { Study } 2-\text { at work: } \\
\text { Joy } \\
\text { Pride } \\
\text { Anger } \\
\text { Guilt }\end{array}$} \\
\hline Complexity & & \\
\hline Importance & & \\
\hline Typicality & & \\
\hline
\end{tabular}

\begin{tabular}{|c|c|c|}
\hline CAPTION & \multirow[t]{3}{*}{ within } & Well-being \\
\hline Negative valence & & \multirow{3}{*}{$\begin{array}{l}\text { Study } 1 \text {-after work: } \\
\text { Emotional exhaustion } \\
\text { Positive affect } \\
\text { Negative affect }\end{array}$} \\
\hline Positive valence & & \\
\hline$\underline{\text { Adversity }}$ & \multirow{5}{*}{$\begin{array}{l}\mathrm{H} 2 \\
\mathrm{H} 2 \\
\end{array}$} & \\
\hline humor & & \multirow{4}{*}{$\begin{array}{l}\text { Study } 2-\text { at work: } \\
\text { Joy } \\
\text { Pride } \\
\text { Anger } \\
\text { Guilt }\end{array}$} \\
\hline Complexity & & \\
\hline Importance & & \\
\hline Typicality & & \\
\hline
\end{tabular}

Figure 1. Proposed conceptual model presenting Hypotheses 2 and 4 at the between- and at the within-person level for Study 1 and Study 2. Hypothesis 2 suggests that specific affective dimensions of CAPTION (Adversity and hum $\underline{\text { r }}$ ) explain daily well-being in form of emotional exhaustion, positive affect, and negative affect after work (Study 1$)$ and in form of the discrete emotions joy, pride, anger, and guilt directly after the event (Study 2) over Positive and Negative valence of work events alone at the between-person level and at the within-person level. Hypothesis 4 suggests that cognitive and typical dimensions of CAPTION (Complexity, Importance, and Typicality) explain daily well-being in form of emotional exhaustion, positive affect, and negative affect after work (Study 1) and in form of the discrete emotions joy, pride, anger, and guilt directly after the event (Study 2) over Positive and Negative valence of work events alone at the between-person level and at the within-person level. 


\section{Appendix}

Examples of Work Events Described by Participants and their Ratings on the CAPTION-SF

Scale

\begin{tabular}{|c|c|c|c|c|c|c|}
\hline & \multicolumn{6}{|c|}{ Event description } \\
\hline & $\begin{array}{l}\text { A regular } \\
\text { customer } \\
\text { complained } \\
\text { that she has } \\
\text { received the } \\
\text { wrong } \\
\text { medication. }\end{array}$ & $\begin{array}{l}\text { Mail from a } \\
\text { colleague } \\
\text { who tried to } \\
\text { avoid } \\
\text { regulations } \\
\text { and tried to } \\
\text { pull me over } \\
\text { the barrel. I } \\
\text { insisted on } \\
\text { the typical } \\
\text { regulation. }\end{array}$ & $\begin{array}{l}\text { A company } \\
\text { that I tried to } \\
\text { reach for } \\
\text { three weeks } \\
\text { finally called } \\
\text { back. }\end{array}$ & $\begin{array}{l}\text { Pep-talk from } \\
\text { a colleague } \\
\text { on all the } \\
\text { literature that } \\
\text { I have to } \\
\text { read. }\end{array}$ & $\begin{array}{l}\text { A colleague } \\
\text { was in a bad } \\
\text { mood. }\end{array}$ & $\begin{array}{l}\text { The phone } \\
\text { did not stop } \\
\text { ringing. }\end{array}$ \\
\hline \multicolumn{7}{|l|}{ Complexity } \\
\hline Scholarly & 0 & 0 & 1 & 2 & 0 & c \\
\hline Academic & 0 & 0 & 0 & 3 & 0 & c \\
\hline Analytical & 0 & 3 & 0 & 3 & 0 & 1 \\
\hline Instructional & 0 & 2 & 0 & 0 & 0 & 1 \\
\hline \multicolumn{7}{|l|}{ Adversity } \\
\hline Frustrating & 4 & 4 & 0 & 0 & 4 & 3 \\
\hline Stressful & 3 & 2 & 0 & 0 & 4 & 3 \\
\hline Tiresome & 4 & 4 & 0 & 0 & 4 & 3 \\
\hline Fatiguing & 4 & 2 & 0 & 0 & 3 & 3 \\
\hline \multicolumn{7}{|l|}{ Positive } \\
\hline \multicolumn{7}{|l|}{ Valence } \\
\hline Precious & 0 & 0 & 4 & 3 & 0 & c \\
\hline Cherished & 0 & 0 & 4 & 1 & 0 & 1 \\
\hline $\begin{array}{l}\text { Heart- } \\
\text { warming }\end{array}$ & 0 & 0 & 2 & 2 & 0 & 0 \\
\hline Sentimental & 4 & 3 & 0 & 0 & 2 & $c$ \\
\hline \multicolumn{7}{|l|}{ Typicality } \\
\hline Regular & 3 & 4 & 0 & 2 & 2 & 1 \\
\hline Usual & 3 & 4 & 0 & 1 & 2 & 3 \\
\hline Standard & 2 & 3 & 0 & 0 & 0 & 2 \\
\hline Typical & 2 & 3 & 0 & 1 & 1 & \\
\hline \multicolumn{7}{|l|}{ Importance } \\
\hline Productive & 2 & 0 & 4 & 2 & 0 & 2 \\
\hline Effective & 0 & 2 & 4 & 2 & 0 & 2 \\
\hline Useful & 0 & 2 & 4 & 2 & 0 & 2 \\
\hline Helpful & 0 & 1 & 4 & 3 & 0 & \\
\hline \multicolumn{7}{|l|}{ Humor } \\
\hline Goofy & 1 & 3 & 0 & 0 & 3 & c \\
\hline Wacky & 0 & 0 & 0 & 0 & 0 & c \\
\hline Mischievous & 1 & 2 & 0 & 0 & 3 & $c$ \\
\hline Childish & 2 & 3 & 0 & 0 & 3 & c \\
\hline \multicolumn{7}{|l|}{ Negative } \\
\hline Valence & & & & & & \\
\hline Repulsive & 0 & 3 & 0 & 0 & 3 & c \\
\hline Malicious & 0 & 3 & 0 & 0 & 2 & c \\
\hline Grotesque & 2 & 2 & 0 & 0 & 2 & c \\
\hline Despicable & 2 & 2 & 0 & $\underline{0}$ & 2 & $c$ \\
\hline
\end{tabular}

